\title{
A fifteenth-century shipwreck with Scandinavian features from Bremen. Interpreting the Beluga ship in the context of late medieval clinker construction in northwestern Europe
}

\author{
DANIEL ZWICK
}

Zwick, D. 2019. A fifteenth-century shipwreck with Scandinavian features from Bremen. Interpreting the Beluga ship in the context of late medieval clinker construction in northwestern Europe. AmS-Skrifter 27, 187-206, Stavanger, ISSN 0800-0816, ISBN 978-82-7760-183-0.

\begin{abstract}
While most of this volume's contributions trace Hanseatic influences throughout the North Atlantic, this paper examines a possible counter-influence in the shape of a medieval shipwreck discovered in Bremen in 2007, the construction of which is reminiscent of the Scandinavian shipbuilding tradition. With its radially cleft planks, inlaid wool caulking and clinkerfastenings, the wreck displays a number of features that point typologically to a vernacular Scandinavian origin. However, the planks fall into two groups outside of Scandinavia: high quality wainscot planks cut in the Baltic region in the course of the fourteenth century, and a group of locally cut timber - arguably for repairs - dating from the second quarter of the fifteenth century. This period coincides with a peak of Baltic timber export, especially wainscot for shipbuilders. Hence, the wreck is discussed within the wider context of clinker-built wrecks from this period in general and wrecks built of Baltic oak in particular.
\end{abstract}

Daniel Zwick, Archäologisches Landesamt Schleswig-Holstein, Brockdorff-Rantzau-Str. 70,

D-24837 SCHLESWIG, GERMANY.E-mail: d.zwick@archaeologia-navalis.org

Keywords: baltic timber, timber trade, timber-working, ship building, clinker

\section{Introduction}

A medieval shipwreck dubbed the 'Beluga ship' was discovered in 2007 in the course of the rescue excavation in the construction pit at Bremen's Teerhof. ${ }^{1}$ The site is located on a promontory dividing River Weser from a side arm. The Beluga ship is the first medieval shipwreck in this city with notable traditional Scandinavian features. ${ }^{2}$ It thus complements the great variety of shipwrecks discovered in Bremen so far (Fig. 1, no. 7). The presence of wrecks of both inland and seagoing craft emphasises Bremen's role as international port of transhipment, connecting the hinterland with the North Sea.

This paper is divided into three main sections, the first being a brief summary of technical details, followed by an evaluation in which the Beluga ship is set in the context of other wrecks in north-western Europe in terms of construction and timber provenances and, in conclusion, the implications of the assumed Scandinavian origin and the local site context in the Lower Weser region are explored.

\section{Principal construction features of the Beluga ship}

The inconspicuous wreck remains contain a multitude of information of the way of construction, although only a slab of planking of $c .7$ m length has survived. ${ }^{3}$ The wreck is a traditional lapstrake construction (Fig. 2), entirely clinker-built with radially cleft oak planks with widths ranging between $20-26 \mathrm{~cm}$ and a mean thickness of $2.1 \mathrm{~cm}$. These are connected with square-shanked clinker-nails (rivetted nails with rectangular roves) measuring $c .2 .5$ by $2.3 \mathrm{~cm}$, with a thickness of $0.6 \mathrm{~cm}$. The lands - the overlapping edges of clinker planks or strakes - between the planks were 


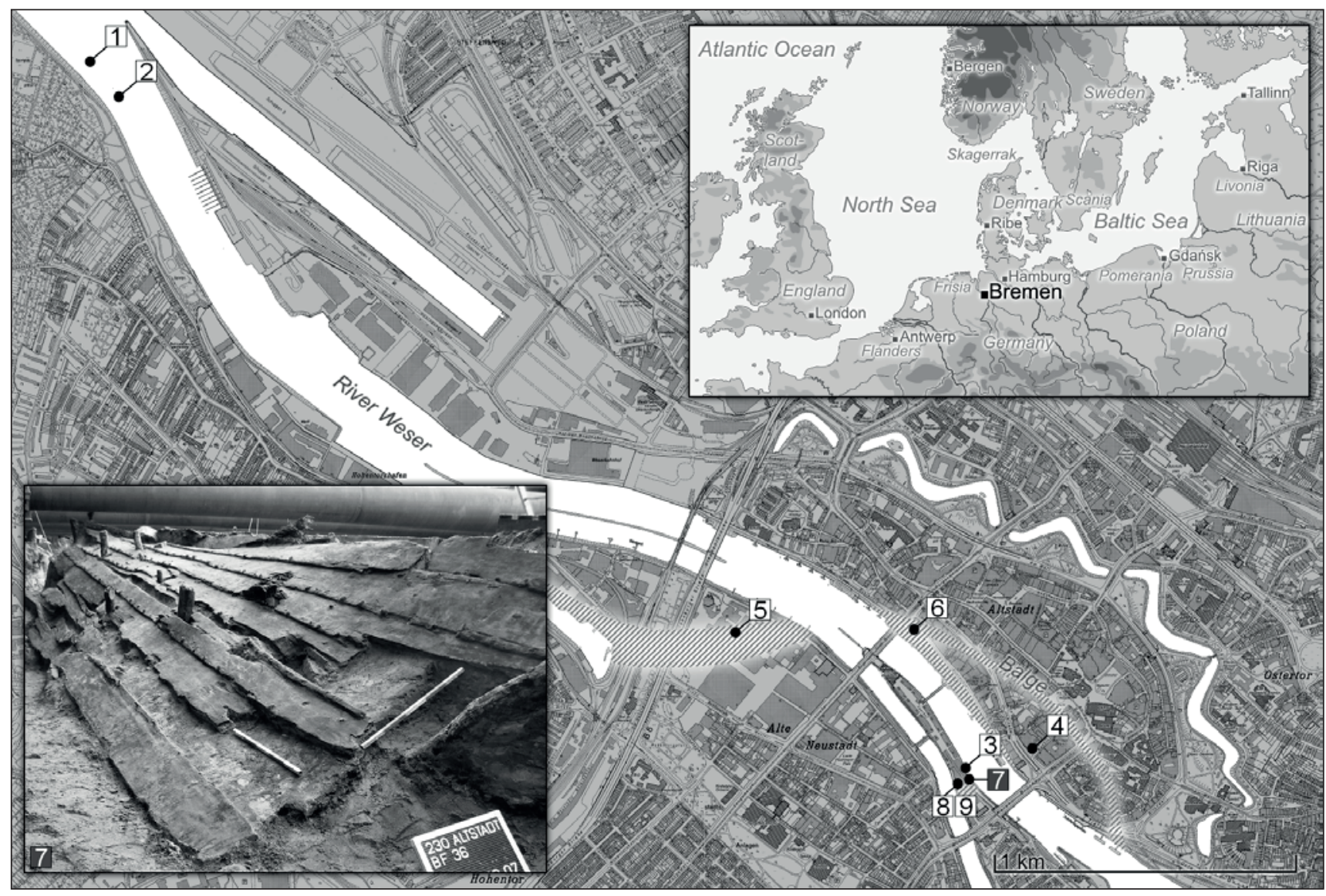

Fig. 1. Overview of medieval and post-medieval wreck finds in the city of Bremen: [1] 'Bremen Cog' (c. 1380)discovered in 1962, [2] Parts of a 'pram' (1070-1240) and a log-boat-discovered in 1972/78, [3] Teerhof ship I (c. fifteenth century) - discovered in 1978, [4] Pram 'Karl' (c. 808) - discovered in 1989, [5] Becks ship (c. 1444) - discovered in 1989, [6] Schlachte ship (c. 1170) - discovered in 1992, [7] Beluga ship (early fifteenth century) discovered in 2007, [8 and 9]: two river barges (late seventeenth century) - discovered in 2007. The Balge tributary - which still served as harbour for inland vessels up to the fifteenth century - and a former side arm of the Weser River are indicated by the hachured area (illustration: Daniel Zwick, basis data from TopSoKa 1:10 000 (c) Geoinformation Bremen, licensed on 22.07.2011).

waterproofed with tarred wool as inlaid caulking. The waterproofing technique in vessels built of radially cleft planks was more difficult, as the surfaces were more uneven than sawn planks. ${ }^{5}$ This explains the ample quantities of caulking material used. Evidence from Britain, Norway ${ }^{6}$ and Denmark ${ }^{7}$ has shown that the overlapping lands of clinker constructions were almost exclusively caulked with animal fibres up to the late medieval period, with the exception of the scarf joints. ${ }^{8}$

The constructional characteristics observed in the Beluga ship are typical for Scandinavia, to a certain extent the British Isles and other parts of northern Europe, and very distinctive from contemporary wrecks in the southern North Sea litoral. This includes also the keel and stem construction. Both components are connected by a diagonal scarf of a length of $c$. $25 \mathrm{~cm}$. The absence of garboard rabbets ${ }^{9}$ in the keel indicates a greater deadrise angle ${ }^{10}$ than would have been common with T-shaped or plank keels, with the garboards running almost vertically. ${ }^{11}$ This would have added lateral stability to decrease side drift. Another marker of seakeeping capabilities can be inferred from frame distances. Although no frames have survived, as they had been evidently removed for reuse - indicating that the vessel was scrapped - rows of trenails indicate their former presence at intervals of $50 \mathrm{~cm}$, a very common distance for small and medium-sized vessels.

The interpretation of the Beluga ship as a visiting Scandinavian trader would have been straightforward, if not for the surprising result of the dendrochronological analysis: none of the analysed planks actually originated from Scandinavia. The first dendrochronological samples taken from the fragmentary upper planks yielded a result from the second quarter of the 


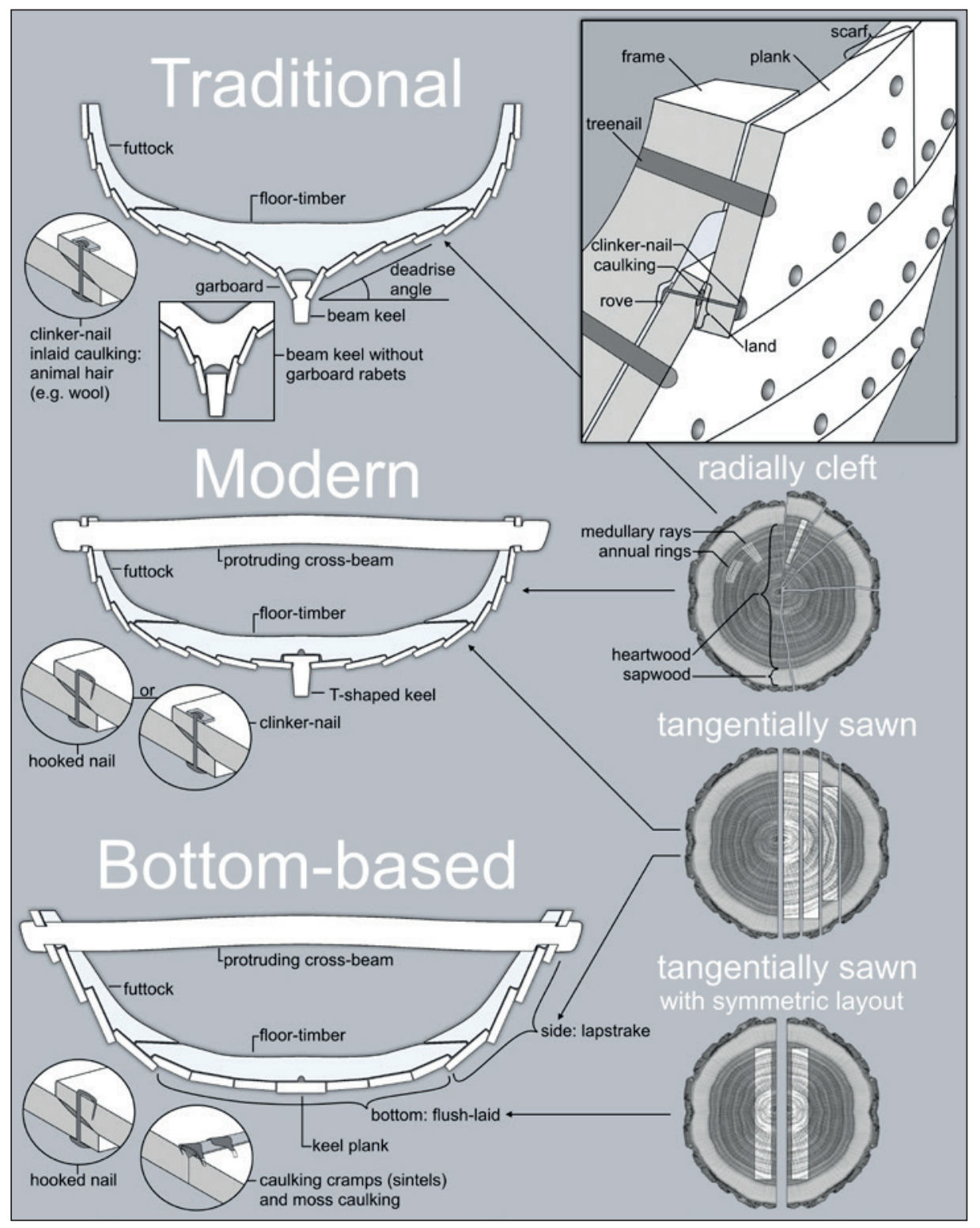

Fig. 2. Schematic overview of the three principal late medieval lapstrake constructions. The distinction between 'traditional' and 'modern' types is based on Bill 2009b. The comparative part of this study only examines traditional and modern lapstrake constructions, but not bottom-based constructions (see also Fig. 4, Tables 2 and 4). The type representations are schematic and modular deviations apply in several cases. The timber crosssections as shown on the right side highlight the basic difference of radially cleft and tangentially sawn planks (see also Table 1) and their use in shipbuilding (illustration: Daniel Zwick).

fifteenth century with a provenance from the Weser lowland. Wood in riverine lowland regions is subject to unique conditions which lead to a distinctive regional annual ring growth by which their provenance can be closely determined. ${ }^{12}$ Further samples from the lowermost strakes were analysed and not only antedate the latter by a few decades, but originated from an entirely different region: the Baltic region (Fig. 3).

None of the planks contained sapwood, so in neither case could an exact felling date be ascertained. For that reason a margin of fourteen years was added for the Baltic planks ${ }^{13}$ and the regular twenty-year margin for the locally cut planks, though both could have been considerably greater. ${ }^{14}$ Strikingly, the Baltic planks feature great variations in start-end dates. This could be explained by the way planks were extracted from the parent tree. They might have been extensively dressed along the edges to fashion the planks in uniform widths. This would support the interpretation that this was imported timber - such as wainscot - as vessels build of locally cut timber would feature a much more uniform pattern. The dimensions of wainscot planks were often standardized to make them suitable for exports, so the tree-trunk would have been seldom exploited to the maximum width. The Baltic region was heavily forested, so there was no necessity to make best use of the timber - to use the last ring before the sapwood or even the sapwood - as in regions where timber scarcity prevailed.

The traditional - if not downright 'antiquated' Scandinavian ${ }^{15}$ - way of construction was to a certain extent conditioned by the supply of suitable timber, which was of the highest quality oak, virtually knotless and straight-grained in the case of the Beluga ship. The 


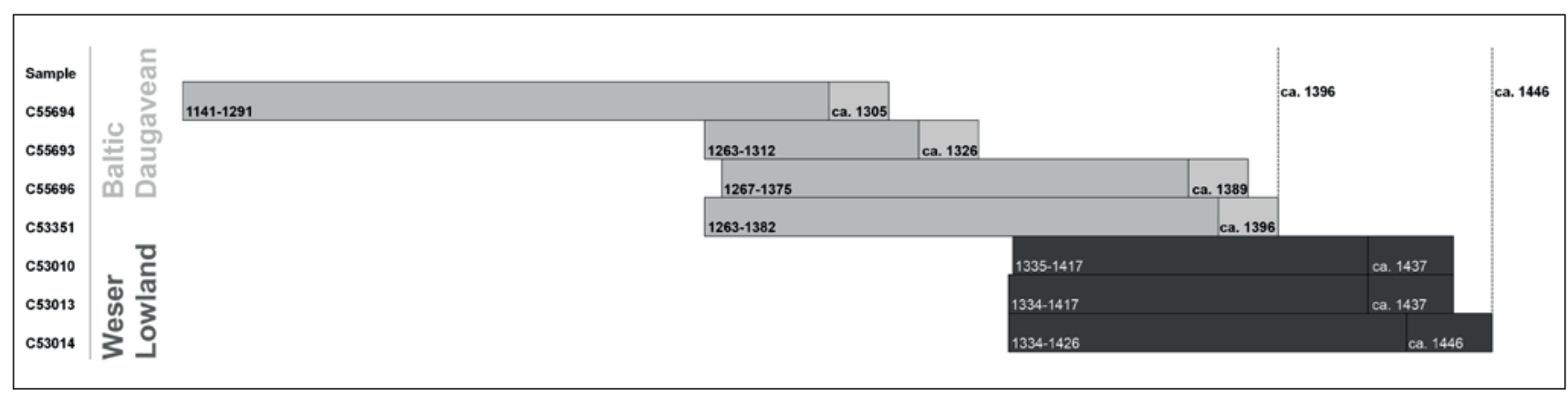

Fig. 3. Bar diagram showing the dendrochronological results of the analysed planks from the Beluga ship, which fall into two groups: an earlier group of timber cut in the Baltic area (C53351, C55693, C55694, C55696) and a later group from the Weser Lowland (C53010, C53013, C53014), thus in direct proximity to where the ship was scrapped. Due to the lack of sapwood the cutting dates are approximate values, which may explain the great chronological gaps in the first group (analysis: Karl-Uwe Heußner, illustration: Daniel Zwick).

base material and workmanship of the planks is not a random construction feature, but of central importance for the wreck's interpretation.

\section{The significance of the Baltic timber}

While it is not possible to determine the exact provenance for Baltic oak timber, ${ }^{16}$ not least due to the extensive hinterland where Baltic oak was cut and floated down the Daugava River to Riga, ${ }^{17}$ the quality itself indicates that the timber was cut in a wildwood area. In such woods, the lower branches die off early and are grown over due to the overarching shade provided by treetops, leaving small knots only in the first few growth rings. ${ }^{18}$ In contrast to the heavily branched trees in central European managed woodlands, wildwood trees have tall straight-grained trunks which are easily cleft, and planks can be of much greater lengths. ${ }^{19}$ Timber supply directly affects the type of timber conversion and ultimately the shipbuilding technique.

The Beluga ship is not only distinctive in terms of construction compared to the so-called 'Bremen Cog' from around 1380, but also in terms of its wood supply. The tangentially sawn timber used as planks in the 'Bremen Cog' were of such bad quality, that even during the initial construction some cracks needed to be patched. ${ }^{20}$ Its planks were made of logs floated down the Weser River from the Weser mountains and reflects little choice in oak supply. These logs could not have been cleft in a similar way as those in the Beluga ship, due to their knotty nature, which would have resulted in a contorted twisted plank with many weak spots. Thus, it would have been impossible to build the Beluga ship with the kind of wood available to the builders of the 'Bremen Cog', so the reliance on high

\section{Table 1. Comparison of timber conversion techniques.}

\section{Radial cleaving}

- allowed the planks to be thinner, as the medullary rays were left intact which add to the planks' strength, thus making the planks more flexible and lighter

- radially cleft planks are watertight, thus regularly also used as barrel staves

- better nail hold in radially split edge-wood

\section{Tangential sawing}

- the girth of the trunk could be fully exploited as almost the entire diameter was used,

- this decreased the number of lands and thus the effort to connect and caulk them

- the truncation of medullary rays was compensated by greater plank thicknesses, which accounted for greater overall robustness - the processing of tangentially sawn timber arguably afforded lesser skills, and opened more options to work low-quality timber, like patching over cracks and knots

quality import timber from the Baltic was very much the precondition for this construction.

Sawing is commonly regarded as the more modern way of timber conversion and associated to urban shipbuilding, whereas radial cleaving is often regarded as old-fashioned or traditional. ${ }^{21}$ However, shipbuilding techniques perceived as innovative could have been primarily driven by cost-benefit assessments or scarcity of adequate timber, rather than a progression in technology in its own right, since both methods have advantages and drawbacks alike (Table 1).

The comparatively modest dimensions of radially cleft planks do not necessarily point to a modestly sized vessel. Seán McGrail tentatively addressed the issue of estimating ship-sizes on the basis of dimensions of individual ship-timbers and, interestingly, did not include plank width as criteria, probably for a good reason. ${ }^{22}$ The Dokøen 3 wreck ${ }^{23}$ discovered in Copenhagen dates to $c .1423$ and is about $13 \mathrm{~m}$ in length and likewise 
planked with imported wainscot boards with widths and thicknesses averaging $24 \mathrm{~cm}$ and $2.75 \mathrm{~cm}$, respectively. ${ }^{24}$ And the clinker-wreck from Aber Wrac'h has very modest plank, keel and stem dimensions despite its great overall length of approximately $25 \mathrm{~m}$. Like the Beluga ship, its hull was preserved on the one side only to the eighth strake, but had as many as 24 strakes on the other side. ${ }^{25}$

Since a great number of other clinker-built wrecks were also built of imported timber, it is interesting to explore whether there is a link between the use of Baltic timber and constructional preferences in late medieval clinker-built vessels.

\section{Evaluating the link between Baltic timber trade and clinker-built vessels}

Suitable timber - particularly timber needed for shipbuilding - became a scarce resource with the demographic evolution in the densely urbanized central Europe during the later Middle Ages, and the deforestation in its wake. This prompted the emergence of extensive transport networks for timber, so shipbuilders in urban regions with staple rights on timber, could choose from a wide range of sources. Shipbuilders from Newcastle, for instance, were able to buy timber from as many as 50 different sources. ${ }^{26}$

The use of timber exported from the eastern and southern coasts of the Baltic Sea for the construction of clinker-built ships was not exceptional. ${ }^{27}$ Baltic timber trade started already in the thirteenth century. Wreck fragments of Baltic oak are known from Dordrecht, the Netherlands, dating to the early thirteenth century, ${ }^{28}$ numerous reused planks from the early fourteenth century in London's port, ${ }^{29}$ and from herring vessels in Flanders from the late fourteenth century. ${ }^{30}$ English inventories dating between 1272 to 1377 reveal the extent to which clinker-galley ${ }^{31}$ shipbuilders relied on imported materials, like boards de Estlond traded by merchants with connections to Holland, Prussia and Sweden, which appear to have been used particularly for garboards and strakes near thereto, while the upper strakes were often augmented by locally cut wood of lower quality. ${ }^{32}$ The same could have been the case in the Beluga ship, where high quality Daugavian oak was used for the lowermost strakes where the bending stresses would have been the greatest. Knot-free straight-grained oak from Baltic wildwoods would have been also available in greater lengths and would have reduced the number of scarfs considerably, which would have been important for the submerged part of the hull. ${ }^{33}$ Thus the planks from the upper strakes hewn in the Weser lowland do not necessarily indicate a later repair, but could also reflect a very considerate cost-benefit assessment, in that the expensive wainscot planks were not wasted on less critical parts of the hull.

Timber exports via Danzig (Gdańsk) peaked in the fourteenth and fifteenth centuries ${ }^{34}$ and shifted to Königsberg (Kaliningrad) and Riga in the course of the sixteenth century. ${ }^{35}$ This is very much reflected by the provenances of oak planks of fourteenth-/fifteenthcentury medieval shipwrecks found throughout the North Sea area (Fig. 4).

All major Baltic Sea ports where timber was exported were controlled by the Teutonic Order for most of the time span discussed here and, significantly, the Order was the only territorial power to be also a member of the Hanse. In several instances Teutonic Order agents were directly involved in negotiating timber trade deals with Polish merchants, ${ }^{36}$ and the Großschäffer who conducted trade and shipping in the Order's interest was granted special trading privileges, most notably the monopoly on amber trade, but was also freed from all sorts of other export bans. ${ }^{37}$ At the peak of the EnglishPrussian conflict (1385-1388), the Teutonic Order enforced a Hanseatic export ban on timber required for shipbuilding in $1386 .{ }^{38}$ This highlights its central role as timber supplier within the Hanse.

The written sources indicate that timber from Danzig was principally exported to Flanders and England, ${ }^{39}$ but the share of wrecks built of Vistulian timber along the Norwegian coastline - particularly in the Skagerrak and Kattegat region - appears disproportionally high at first glance (Fig. 4). The Pfundzollliste (the poundtoll register) of Danzig for the year 1409, however, mentions only three merchants directly engaged in trade with Scandinavia, one with Scania and two with Sweden, ${ }^{40}$ so it seems unlikely that these vessels were locally operated. A possible explanation for this disproportionality is that these shipwrecks were long-distance traders, as indicated by their considerable sizes, namely the late fourteenth- /early fifteenth-century wrecks of Bøle (length: $+20 \mathrm{~m}$ ), Skjernøysund (+ 26 $\mathrm{m})$, Avaldsnes $(22 \mathrm{~m})$ and Skaftö $(25 \mathrm{~m})$ (Table 2). If that was the case, they will have most likely frequented a major Hanseatic artery of trade, which carried Baltic bulk commodities - such as timber - and took further Norwegian export commodities on board - especially herring -which was then directly shipped to Flanders, England or other destinations. ${ }^{41}$ The high concentration 


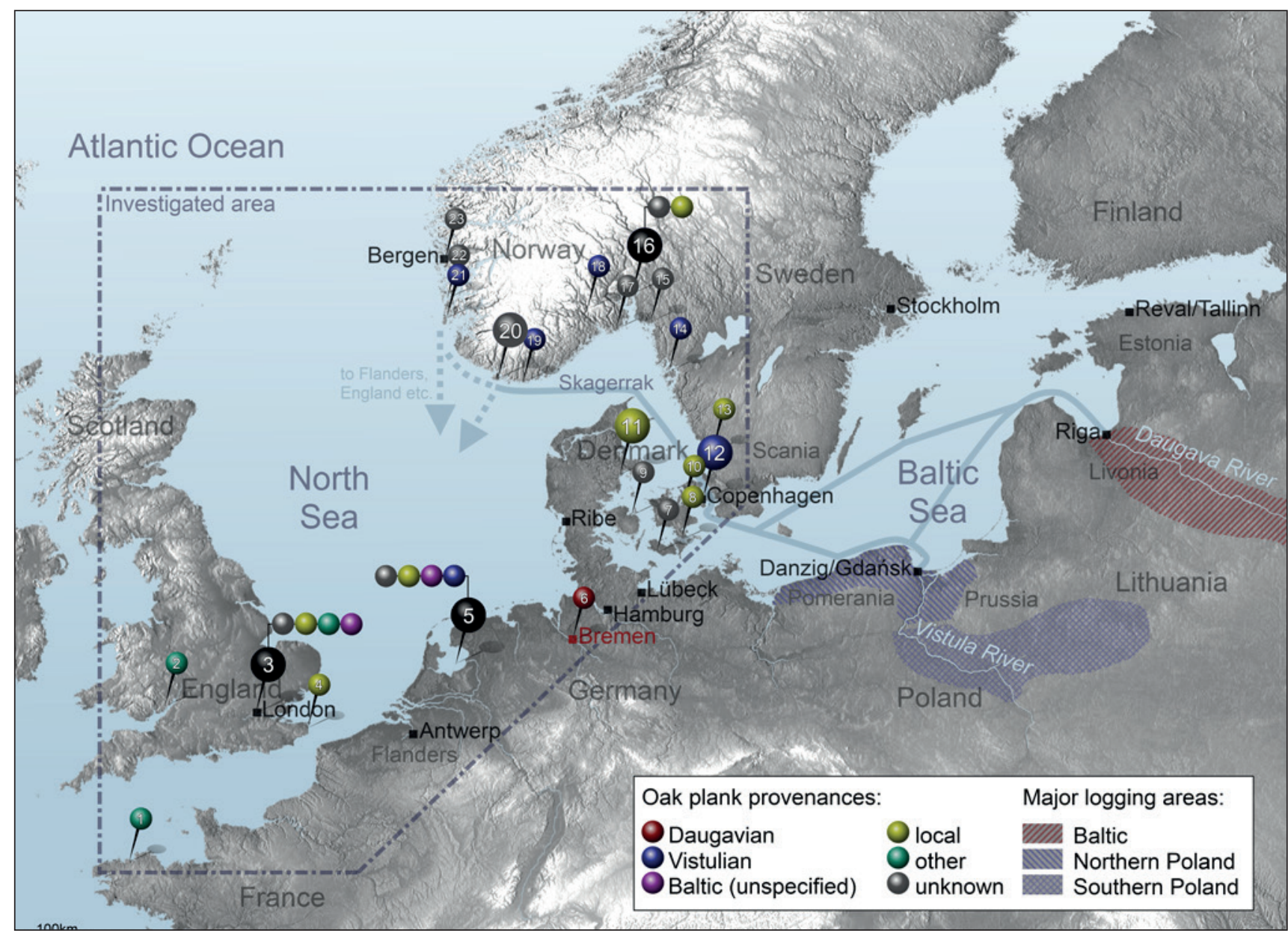

Fig. 4. This overview shows the provenances of oak planks from clinker-built shipwrecks dating between c. 1300 to 1540. The numbers on the pins are itemized as \# in Table 2 and 4. The comparison shows that the Beluga ship (\#6) is unique in having an ascertained Daugavian - i.e. genuinely Baltic - provenance, whereas in several other cases the term 'Baltic' is used in the unspecified sense of originating from the greater Baltic Sea area. This can be attributed to the recent breakthrough in dendro-provenancing, leaving some of the wrecks excavated several decades ago with a less precise or no provenances. In other parts, dendro studies have progressed to determine provenance on a regional scale, as between 'northern Poland' - roughly corresponding to Prussia and Pomerania under the rule of the Teutonic Order - and 'southern Poland' in the Kingdom of Poland (Northern Poland = group $A+B$, southern Poland = group $C+D$, as defined in Haneca et al. 2005, 264). The trade routes from Riga and Danzig as indicated here correspond to the routes detailed in the Hanseatic Sea Book (c. 1470) (illustration: Daniel Zwick).

of shipwrecks clustering around Lindesnes (Fig. 4, no. 20 ) is no coincidence, as Lindesnes was - together with Skudenes - mentioned in the Hanseatic Sea Book of $c$. 1470 as important bearing positions for making a landfall for courses set from the coast of Flanders, a passage which involved the longest distance out of sight of land in the entire book. ${ }^{42}$ While Skudenes on Karmøy marked the entry to Avaldsnes, Lindesnes marked the entry to the Baltic Sea.

The central eastern European hinterlands were not the only sources for wildwood timber, as suggested by a slab of articulated planking of Irish oak from a late thirteenth-century clinker-galley discovered in
Southwark, London, with plank lengths over $2.5 \mathrm{~m} .{ }^{43} \mathrm{In}$ contrast to Ireland, however, Baltic, Prussian and Polish timber could be supplied from a far more extensive hinterland, made accessible by the great river systems of the Vistula and Daugava and their numerous tributaries reaching deep into the Polish, Lithuanian and Russian hinterlands. Thus, the depletion of timber as a raw commodity was not an imminent concern, and an infrastructure for the seaborne export of timber could develop, as the foundation of a saw-mill in Danzig in 1338 shows. The saw-mill converted the trunks floated down the river into boards. ${ }^{44}$ There is also documentary evidence from the Vistula River that logs were 
Table 2. Lapstrake constructions from c. 1300 to 1540 in the North Sea region. ${ }^{1}$ The numbers (\#) relate to the find locations as shown in Fig. 4. The principal aim of this overview is to set the oak plank provenances in relation to the method of timber conversion and plank dimensions. ${ }^{2}$

\begin{tabular}{|c|c|c|c|c|c|c|c|c|c|c|c|c|c|c|c|}
\hline Wreck & $\#$ & 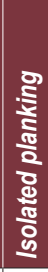 & 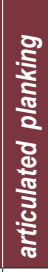 & 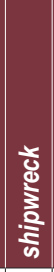 & ฐัँ & 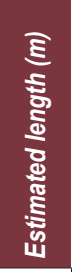 & 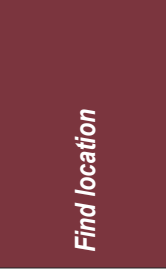 & ड़े & 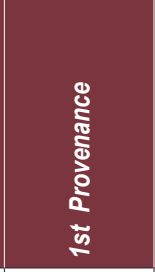 & 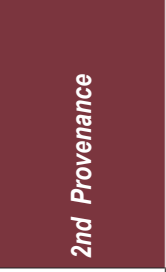 & 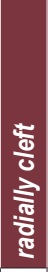 & 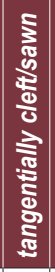 & 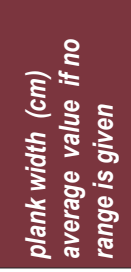 & 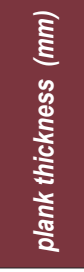 & 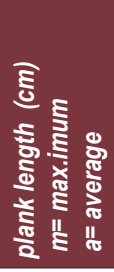 \\
\hline Kingston & 3 & & $x$ & & $1275 \pm 25$ & & London & UK & & & $x$ & C & & 35 & \\
\hline TYT98 & 3 & & $x$ & & $1276 \pm 11$ & & London & UK & E-Ireland & & $x$ & & & $40-45$ & \\
\hline Vestre Skars & 7 & & & $x$ & 1300 & $12+$ & Hominde & DK & & & & & & & \\
\hline Halmstad & 13 & & & $x$ & 1302 & 16 & Halmstad & SE & W-Sweden & & $x$ & & & & \\
\hline Sørenga 3 & 16 & & & $x$ & $1320+$ & $12+$ & Oslo & NO & S-Norway & & & & & & \\
\hline Bryggen & 23 & & $x$ & & $1332+$ & & Bergen & NO & & & & & $18-27$ & & $\mathrm{~m} 250+$ \\
\hline Roskilde Havn 1 & 10 & & & $x$ & 1336 & 9 & Roskilde & DK & E-Danmark & & $x$ & & & & \\
\hline Hundevika & 20 & & & $x$ & $1340 \pm 60$ & 15 & Farsund & NO & & & & & $25-30$ & 40 & \\
\hline Hays-Symonds Wharf & 3 & $X$ & & & $1340+$ & & London & UK & U-Baltic & & $x$ & & $17-30$ & $35-58$ & \\
\hline Southwark & 3 & & $x$ & & $1344-1368+$ & & London & UK & U-Baltic & & $x$ & & & $21-30$ & \\
\hline Sandwich & 4 & & $x$ & & $1347 \pm 15$ & & Sandwich & UK & S-England & & $x$ & & 30 & $40-60$ & m198 \\
\hline Sørenga 1 & 16 & & & $x$ & $1350+$ & $12+$ & Oslo & NO & & & & & & & \\
\hline Sørenga 2 & 16 & & & $x$ & $1355+$ & $15+$ & Oslo & NO & SW-Sweden & E-Denmark & & & $17-32$ & 25 & \\
\hline $\begin{array}{l}\text { Hays W-Abbots } \\
\text { Lane }\end{array}$ & 3 & $x$ & & & $1362+$ & & London & UK & $\begin{array}{c}\text { British Isles, } \\
\text { Germany }\end{array}$ & U-Baltic & $x$ & & $17+$ & $25-30$ & \\
\hline Hays-W-G\&S Wharf & 3 & $X$ & & & $1370+$ & & London & UK & U-Baltic & & $x$ & & 36 & $54-60$ & \\
\hline Isegran & 15 & & & $x$ & $1370 \pm 50$ & 15 & Fredrikstad & NO & & & & & $20-27$ & & \\
\hline Sundekilen & 17 & & & $x$ & $1375 \pm 70$ & $15+$ & Sandefjord & NO & & & & $S$ & $18-30$ & $25-30$ & \\
\hline Kerteminde 1 & 9 & & $X$ & & 1380 & & Kerteminde & DK & & & $x$ & & & 28 & \\
\hline Bøle & 18 & & & $x$ & $1386 \pm 10$ & $20+$ & Skienselva & NO & N-Poland & & & $S$ & & & \\
\hline Skjernøysund 3 & 19 & & & $x$ & 1390 & $26+$ & Skjernøysund & NO & Poland & & $x$ & $S$ & $33-38$ & $40-50$ & a870 \\
\hline Avaldsnes & 21 & & & $x$ & $1392+$ & 22 & Avaldsnes & NO & N-Poland & & & & 35 & 40 & \\
\hline Beluga & 6 & & $x$ & & $1396+/ 1446+$ & $7+$ & Bremen & $\mathrm{DE}$ & Baltic s & Lower Weser & $x$ & & $20-26$ & 21 & $\mathrm{~m} 400+$ \\
\hline Blackfriars 3 & 3 & & & $x$ & $1398 \pm 18$ & 14.6 & London & UK & & & $x$ & & $23-27$ & $25-50$ & \\
\hline Dokøen 2 & 12 & & & $x$ & $1405 / 1425$ & $10+$ & Copenhagen & DK & N-Poland & & $X$ & $S$ & & & \\
\hline Ny Hellesund 2 & 20 & & & $x$ & 1410 & $16+$ & Lindesnes & NO & & & & & 45 & $40-50$ & \\
\hline Århus Å & 11 & & & $x$ & $1411+$ & $14+$ & Århus & DK & & & $x$ & & & & \\
\hline Dokøen 4 & 12 & & $x$ & & 1415 & & Copenhagen & DK & Poland & & $x$ & & & & \\
\hline Foldrøy & 22 & & & $x$ & $1420 \pm 100$ & & Foldrøy & NO & & & & & $40-50$ & $30 / 50$ & a940 \\
\hline G35 & 5 & & & $x$ & $1422 \pm 6$ & 19 & Zuiderzee & $\mathrm{NL}$ & Netherlands & Westphalia & & & & & \\
\hline Dokøen 3 & 12 & & & $x$ & $1423 \pm 3$ & & Copenhagen & DK & Poland & & $X$ & $S$ & 24 & 28 & m687 \\
\hline Skaftö & 14 & & & $x$ & $1430+$ & 25 & Skaftö & SE & N-Poland & & $x$ & & $35-40$ & $35-40$ & \\
\hline Selør 4 & 16 & & & $X$ & $1435 \pm 25$ & $20+$ & Oslo & NO & & & & & $20-30$ & 30 & \\
\hline Aber Wrac'h & 1 & & & $x$ & 1435 & & Aber Wrac'h & FR & Basque? & & $x$ & & 23 & 30 & \\
\hline Vedby Hage & 8 & & & $x$ & 1435 & & Storstrømmen & DK & Sealand & Scania & $x$ & C & 20 & 25 & a250- \\
\hline Århus 1 & 11 & & $x$ & & 1440 & & Århus & DK & E-Jutland & & $x$ & & $25-28$ & $25-35$ & $\mathrm{~m} 240+$ \\
\hline Århus 4 & 11 & & $x$ & & 1440 & & Århus & DK & E-Jutland & & & & $12-14$ & 35 & m155 \\
\hline Århus 5 & 11 & & $x$ & & 1440 & & Århus & DK & E-Jutland & & $x$ & & & & \\
\hline Blackfriars 4 & 3 & & & $x$ & $1450 \pm 50$ & & London & UK & & & & & $23-30$ & & \\
\hline Ramslandsvåg & 20 & & & $x$ & $1453 \pm 18$ & $5+$ & Lindesnes & NO & & & & & 30 & & \\
\hline Bankside & 3 & $x$ & & & $1456 \pm 30$ & & London & UK & British Isles & & $x$ & & 13-19 & $15-36$ & \\
\hline
\end{tabular}




\begin{tabular}{|c|c|c|c|c|c|c|c|c|c|c|c|c|c|c|c|}
\hline Wreck & $\#$ & 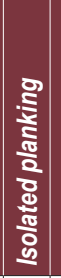 & 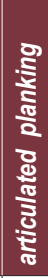 & 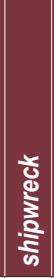 & 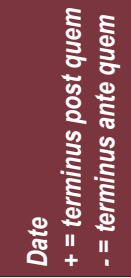 & 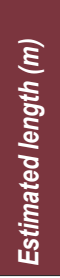 & 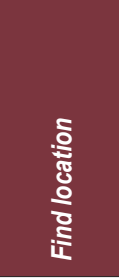 & ड़̃ & 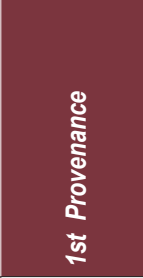 & 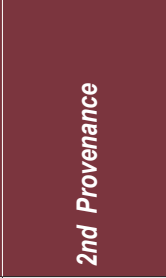 & 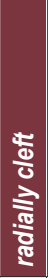 & 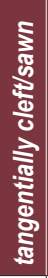 & 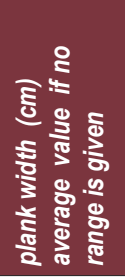 & 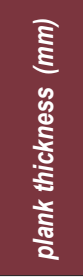 & 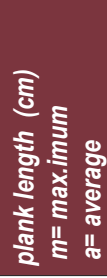 \\
\hline Newport & 2 & & & $x$ & $1458 \pm 10$ & & Newport & UK & Basque? & & $x$ & & 21 & $19-24$ & m451 \\
\hline B 36 & 5 & & $x$ & & 1476 & $18+$ & Zuiderzee & $\mathrm{NL}$ & $\begin{array}{l}\text { NW-Poland, } \\
\text { U-Baltic }\end{array}$ & N-Scandinavia & & & & & \\
\hline Sørenga 9 & 16 & & $x$ & & $1477 \pm 16$ & $6+$ & Oslo & NO & SW-Sweden & Sealand & & $x$ & $20-33$ & 30 & $\mathrm{~m} 470$ \\
\hline $\begin{array}{l}\text { Hays W-Morgans } \\
\text { Lane }\end{array}$ & 3 & $x$ & & & $1490+$ & & London & UK & British Isles & & $x$ & $x$ & $24-25$ & $18-36$ & \\
\hline Sørenga 10 & 16 & & $x$ & & $1493 \pm 32$ & & Oslo & NO & & & $x$ & & $12-27$ & $12-19$ & $\mathrm{~m} 220$ \\
\hline Sørenga 8 & 16 & & $x$ & & $1495 \pm 7$ & & Oslo & NO & S-Sweden & & & $x$ & $18-26$ & $10-31$ & $\mathrm{~m} 467$ \\
\hline Hays Wharf & 3 & & $x$ & & $\begin{array}{l}\text { late } 15 \text { th } \\
\text { century }\end{array}$ & & London & UK & & & $x$ & & & & \\
\hline E 159 & 5 & & & $x$ & $1506 \pm 6$ & & Zuiderzee & $\mathrm{NL}$ & Netherlands & $\begin{array}{l}\text { Westphalia, } \\
\text { S-Sweden }\end{array}$ & & & & & \\
\hline U34 & 5 & & & $x$ & $1528 \pm 6$ & 30 & Zuiderzee & $\mathrm{NL}$ & SE-Poland & & $x$ & $S$ & $\begin{array}{l}30-40 \\
43-53\end{array}$ & $50-60$ & \\
\hline M11 & 5 & & & $x$ & $1532 \pm 1$ & 20 & Zuiderzee & $\mathrm{NL}$ & Netherlands & & & & & & \\
\hline $\mathrm{O} 28$ & 5 & & & $x$ & $1535 \pm 5$ & 17 & Zuiderzee & $\mathrm{NL}$ & U-Baltic & Poland & & & & & \\
\hline Hays W-B Factory & 3 & $x$ & & & $1541+$ & & London & UK & British Isles & & $x$ & & 50 & $30-32$ & \\
\hline J137 & 5 & & & $x$ & $1543 \pm 3$ & 24 & Zuiderzee & $\mathrm{NL}$ & S-Sweden & & & & & & \\
\hline
\end{tabular}

cleft and floated down as semi-products. ${ }^{45}$ At the peak of Vistulian timber exports in the fifteenth century, saw-mills were founded in the logging areas further up the river, so borte, brede, delen were no longer fabricated in Danzig and other timber-exporting ports. ${ }^{46}$ This seems to indicate that wooden products from the Vistula River basin were to a great extent sawn rather than cleft.

What can be said with some certainty is that the archaeological record corroborates the written records in that different categories of prefabricated timbers were exported, primarily defined by size. Three late medieval shipwrecks are known so far in which the cargo included timber products as export commodity. Interestingly, the timber dimensions in all three wrecks were fairly consistent, so that they could be divided into two principal groups (Table 3 ), which can be tentatively associated to some of the forty-one timber-product categories listed in Danzig's Pfundzollliste of 1409: The timbers summarised in group 1 would have had the adequate dimensions to be considered dielen, but they could have also been bottichholz i.e barrel staves. The second group most likely correlates to wainscot, ${ }^{47}$ given the dimensions of the planks and the fact that they were radially extracted from the trunk. ${ }^{48}$

The data compiled from late medieval clinker-built vessels in northwestern Europe conclusively suggests neither a decline in the use of radially cleft planks for a time span of nearly three centuries, nor the exclusive use in smaller vessels like the Beluga ship. Even a fairly large ship built for the high seas (as indicated by the sturdy construction of closely-spaced frames) like the Skjernøysund ship 3 was predominantly planked with radially cleft timber, while sawn planks were used for the internal timbering like stringers and ceiling. ${ }^{49}$ So, the 'antiquated' way of construction often seemed to be the preferred way of construction, even when sawn planks were readily available. This might have been a preference of the shipbuilders, as cleft planks were much more flexible and therefore easier to bend, and Baltic wildwood timber was often also available in greater lengths, which would have reduced the number of scarfs in a strake. Statistically, the peak of Baltic timber exports in the fifteenth century does not manifest in the relative share of determined plank provenances.

\section{Putting the pieces together: the implications of a Scandinavian origin}

Based on its typological characteristics, a building site for the Beluga ship in Scandinavia or Scandinavianinfluenced territories like the British Isles remains most likely, although neither a Baltic nor a local building site can be entirely ruled out. ${ }^{50}$ The most likely 
Table 3. This table summarizes the shipwrecks known to have carried timber as part of their cargo. ${ }^{3}$ All timbers were radially cleft. In the case of the Skaftö wreck only few timbers were recovered from the wreck and the data is therefore less representative. In the case of the Skjernøysund wreck, many timbers have badly deteriorated and are not all preserved to their original dimensions, so the number in the brackets represent the uncertain attributions. ${ }^{4}$ The data suggests two major formats and in the case of the Skaftö wreck, a possible correlation between timber provenance and dimensions of the prefabricated timber.

\begin{tabular}{|c|c|c|c|c|c|c|c|c|c|c|c|}
\hline $\begin{array}{l}\text { shipwreck } \\
\text { with the listed } \\
\text { timber cargo }\end{array}$ & $\begin{array}{c}\text { date of } \\
\text { the timber } \\
\text { cargo }\end{array}$ & $\begin{array}{l}\text { : } \\
\text { : } \\
\text { वे }\end{array}$ & 홍조 & 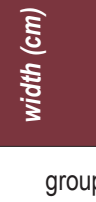 & 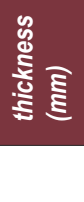 & ) & 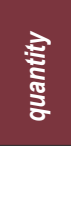 & ड़े & 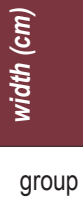 & 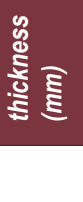 & के छั \\
\hline Skjernøysund 3 & 1394 & $9(6)$ & $50-83$ & $16-$ & 20- & N-Poland & $13(8)$ & 230 & $25-30$ & $40-50$ & N-Poland \\
\hline Gdansk W5 & $1405-1408$ & 205 & $79-85$ & $14.5-16$ & $14-25$ & NE-Poland & 79 & 250 & 30 & $20-45$ & NE-Poland \\
\hline Skaftö & $1437-1441$ & 3 & 85 & $15-17+$ & 20- & N-Poland & 4 & $137+$ & $23-30$ & $30-60$ & SE-Poland \\
\hline
\end{tabular}

scenario of a Scandinavian origin is explored further here, as there can be little doubt about the building tradition. The first indication is given by the use of square-shanked clinker-nails. Originally diagnostic of a Scandinavian origin, they have become a more widespread in northern Europe in late medieval times. ${ }^{51}$ Yet it would have been distinctive of a traditional way of fastening in Bremen and the southern North Sea coast, where double-hooked nails rather than clinkernails were used. The wool caulking particularly points to a southern Scandinavian origin, as almost all late medieval vessels with wool caulking have been discovered in either Danish waters - as the wrecks of Vestre Skarsholm (c. 1300), Dokøen 2 (1405) and Vedby Hage (1435) - or southern Norwegian waters - as the wrecks of Hundevika (1340 \pm 60$)$, Sørenga $8(1495 \pm 7)$ and Sørenga 10 (1493 \pm 32) (Table 4). ${ }^{52}$ Small- and medium-sized vernacular clinker ships were almost only built of radially cleft planks in Denmark up to the post-medieval period..$^{53}$ Outside Scandinavia such planks were not uncommon either as in London, where numerous radially cleft planks - some of a Baltic provenance - from the thirteenth to fourteenth century were either scrapped for re-use ${ }^{54}$ or used in shipconstructions like the Blackfriars 3 wreck from the late fourteenth century. ${ }^{55}$

Another interesting comparison is the frame-spacings, as they indicate the sturdiness of a vessel and thus indirectly reflect the kind of marine environment in which the vessel was expected to operate. Vessels with great frame spacings usually operated in sheltered inland waters, whereas seagoing vessels had narrow frame spacings. The frame spacings of the Beluga ship are most common and, as could be anticipated, would relate to a small- or medium-sized vessel. In the Bryggen excavations in Bergen, Norway, two major clusters of frame distances - measured from centre to centre - of 47-50 cm and 63-65 cm were noted, which may roughly relate to a medieval measure of a short ell $(47.4 \mathrm{~cm})$ and a long ell $(55.3 \mathrm{~cm})$ between the frame edges. ${ }^{56}$ Although the side dimensions of keel and stem of the Beluga ship seem small in comparison to similarly built wrecks, the moulded dimension of the stem with almost $30 \mathrm{~cm}$ suggests that it would have fullfilled the requirements of a seagoing vessel, as the keel would have increased the lateral plan and thereby reduced the side-drift.

The part of the Scandinavian coast closest to Bremen is the Danish west coast of Jutland, particularly the city of Ribe, the only significant Danish port at the North Sea. Unfortunately, there is barely any comparative evidence, with the exception of some loose timbers, such as those from a keelson of the late thirteenthcentury dredged up by a fisherman south off Fanø - at the access to Ribe - with the highest likelihood that its wood came from the Weser region. ${ }^{57}$ Not surprisingly, Ribe had long-standing trade relations to Bremen. But did this also extend to Baltic timber trade?

Oak had in fact become a rare commodity in Jutland, which induced King Christian I of Denmark to forbid the export of oak from Ribe in $1480 .{ }^{58}$ Danish shipbuilders acquired their timber mainly from their provinces in Scania, Blekinge and Halland. ${ }^{59}$ Even so, historical records indicate that wainscot was exported via Riga to Denmark in the eighteenth century. ${ }^{60}$ Documentary records from the fourteenth, fifteenth and sixteenth centuries indicate that merchants from Ribe maintained trading contacts to the Baltic, ${ }^{61}$ 
Table 4. Comparative overview of constructional properties and dimensions of clinker-built wrecks from the North Sea area (see also Fig. 4). ${ }^{5}$ Abbreviations for caulking material: $H=$ animal hair, $M=$ moss, $T=$ textiles, $V=$ vegetable fibre, $W=$ wool. Abbreviations for fasteners: $R=$ rivetted square-shanked nail, $b=$ bent nail. Abbreviations for keel construction: $v=$ vertical scarf, $B=$ beam keel, $F=$ flat, $T=T$-shaped, $U=U$-shaped, $V=V$-shaped (similar to $B$ and $U$ ). ${ }^{6}$

\begin{tabular}{|c|c|c|c|c|c|c|c|c|c|c|c|c|c|c|c|c|c|c|}
\hline & $\#$ & 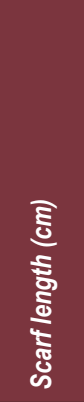 & 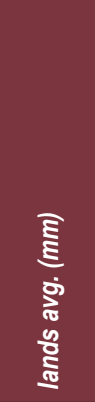 & 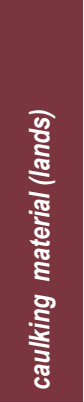 & 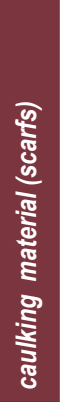 & 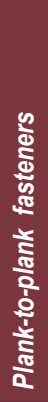 & 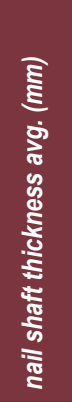 & 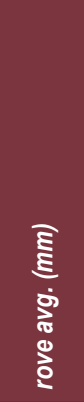 & 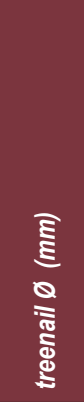 & 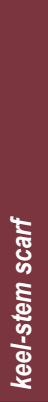 & 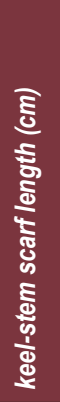 & 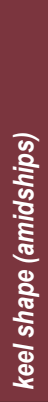 & 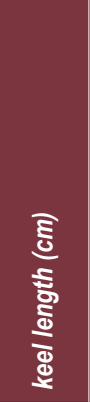 & 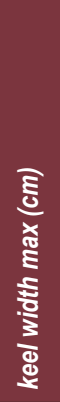 & 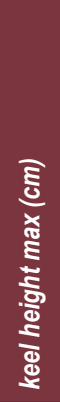 & 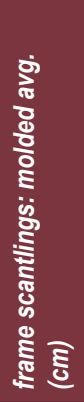 & 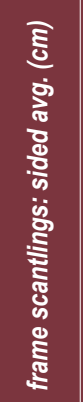 & 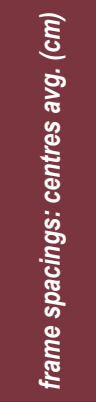 \\
\hline & & \multicolumn{4}{|c|}{ Waterproofing } & \multicolumn{4}{|c|}{ Fasteners } & \multicolumn{6}{|c|}{ Keel construction } & \multicolumn{3}{|c|}{ Frames } \\
\hline Kingston & 3 & long & & $\mathrm{H}$ & & C & & & & & & & & & & $10+$ & $10+$ & 45 \\
\hline TYT98 & 3 & & & & & C & 8 & & $25 / 28$ & & & & & & & & 20 & 40 \\
\hline Vestre Skars & 7 & long & & W? & & $\mathrm{C}$ & & & & & & $U$ & & 18 & & & $12-14$ & 69 \\
\hline Halmstad & 13 & 15 & & $\mathrm{H}$ & & $\mathrm{C}$ & 7 & $23 \times 30$ & 28 & & & $U$ & & 12 & & 15 & 20 & 44 \\
\hline Sørenga 3 & 16 & & & & & C & & & & & & & 860 & & & & & \\
\hline Bryggen & 23 & $10-12$ & & & & $\mathrm{C}$ & & & & & & & & & & & & 65 \\
\hline Roskilde Havn 1 & 10 & $14-26$ & & $\mathrm{H}$ & & C & & & & & & & & & & & & $80-102$ \\
\hline Hundevika & 20 & & $50-75$ & W & & C & & & & & & & & & & $12-18$ & $18-26$ & $10-20$ \\
\hline Hays-Symonds Wharf & 3 & $40-49$ & $33-87$ & $\mathrm{H} / \mathrm{M}$ & M & $\mathrm{C}$ & $5-10$ & & $17-37$ & & & & & & & & & c. $25-45$ \\
\hline Southwark & 3 & & & $\mathrm{H}$ & $\mathrm{H}$ & & & & & & & & & & & & & \\
\hline Sandwich & 4 & 28 & 21 & $\mathrm{H}$ & $\mathrm{H}$ & C & & & & & & & & & & 23 & 33 & $52 \pm 12$ \\
\hline Sørenga 1 & 16 & & & & & $\mathrm{C}$ & & & & & & & & & & & & 65 \\
\hline Sørenga 2 & 16 & & & & & $\mathrm{C}$ & & & & & & $T$ & 1002 & & & & $12-22$ & $80-90$ \\
\hline Hays W-Abbots Lane & 3 & & 44 & & & $\mathrm{C}$ & 8 & & 25 & & & & & & & & & $12-26$ \\
\hline Hays-W-G\&S Wharf & 3 & 40 & $73-94$ & M & & & 10 & & 35 & & & & & & & & & \\
\hline Isegran & 15 & & & & & C & & & & & & & $1000+$ & 16 & 25 & & & $45-55$ \\
\hline Sundekilen & 17 & & & & & $\mathrm{H}$ & 7.5 & & 30 & & & & & & & $12-15$ & $12-15$ & 55 \\
\hline Kerteminde 1 & 9 & 25 & & $\mathrm{H}$ & & $\mathrm{C}$ & & & & & & $\mathrm{T}$ & & 23 & 18 & & & \\
\hline Bøle & 18 & & & & & $\mathrm{C}$ & & & & & & & 1600 & & 30 & & & $40-50$ \\
\hline Skjernøysund 3 & 19 & 50 & $70-80$ & $\mathrm{H}$ & $\mathrm{M}$ & C & 10 & $35 \times 45$ & & v & 26 & B & 1670 & 28 & 45 & $16-20$ & $18-28$ & $5-20$ \\
\hline Avaldsnes & 21 & & & M & M & $\mathrm{C}$ & & & $25 / 33$ & & & & & & & 14 & $14-20$ & 20 \\
\hline Beluga & 6 & $15-20$ & $25+$ & W & W? & C & $4-6$ & $23 \times 25$ & c. 30 & v & 25 & V & $\mathrm{n} / \mathrm{a}$ & 8 & 11 & $\mathrm{n} / \mathrm{a}$ & $\mathrm{n} / \mathrm{a}$ & 50 \\
\hline Blackfriars 3 & 3 & $30-34$ & $70-80$ & $\mathrm{H}$ & & C & 7 & $30 \times 45$ & & & & $\mathrm{~F}$ & & 43 & 14 & 17 & 9 & 47 \\
\hline Dokøen 2 & 12 & $20-23$ & & W & & $C$ & & & & & & & 1000 & & & & 20 & 60 \\
\hline Ny Hellesund 2 & 20 & & & & & $C$ & & & & & & $T$ & & & & 15 & 20 & \\
\hline Århus Å & 11 & $23-35$ & & $\mathrm{H}$ & & $\mathrm{C}$ & $7-8$ & & & & & $T$ & & 12 & & & & $75-80$ \\
\hline Dokøen 4 & 12 & $22-25$ & & $M$ & & & & & & & & & & & & & & 60 \\
\hline Foldrøy & 22 & $50-55$ & & $\mathrm{H}$ & $\mathrm{M}$ & $C$ & & & & & & B & 1620 & & & 15 & $23-30$ & $50-60$ \\
\hline G35 & 5 & & & HWS & & $C$ & & & & & & & & & & & & \\
\hline Dokøen 3 & 12 & $21-25$ & 50 & WTM & HT & $C$ & 7 & $25 \times 30$ & & & & $\mathrm{~T}$ & 979 & 18 & 24 & $8-10$ & $16-20$ & $65-70$ \\
\hline Skaftö & 14 & 50 & $60-100$ & $\mathrm{H}$ & $\mathrm{M}$ & $\mathrm{C}$ & & $30 \times 40$ & & & & $\mathrm{~F}$ & $1400+$ & 45 & 15 & $10-12$ & $11-19$ & $35-40$ \\
\hline Selør 4 & 16 & & & M & W & $\mathrm{C}$ & & & $25-30$ & & & & & 12 & 22 & 20 & $20-22$ & 50 \\
\hline Aber Wrac'h & 1 & $30-40$ & & & M & & & & & & & V & $1000+$ & 24 & 31 & 15 & $15-25$ & 13 \\
\hline Vedby Hage & 8 & $20-30$ & & W & & & & & 30 & & & & & & & & 15 & $38-54$ \\
\hline Århus 1 & 11 & & & $\mathrm{H}$ & $\mathrm{H}$ & C & & & & & & & & & & & & $50-60$ \\
\hline Århus 4 & 11 & & & $\mathrm{HV}$ & & $C$ & & & & & & & & & & & & \\
\hline Århus 5 & 11 & $15-37$ & & $\mathrm{H}$ & & $C$ & & & & & & & & & & & & 62 \\
\hline
\end{tabular}




\begin{tabular}{|c|c|c|c|c|c|c|c|c|c|c|c|c|c|c|c|c|c|c|}
\hline & $\#$ & 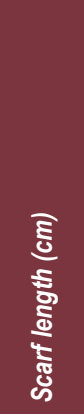 & 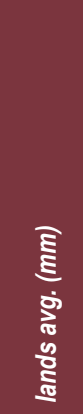 & 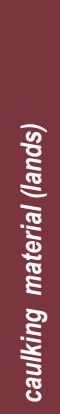 & 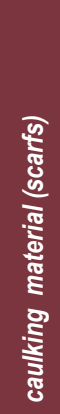 & 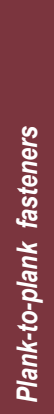 & 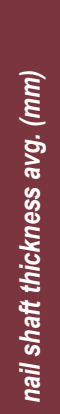 & 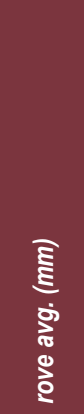 & 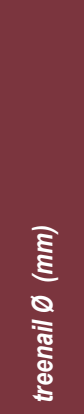 & 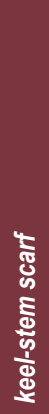 & 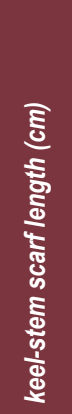 & 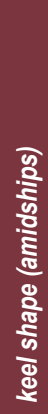 & 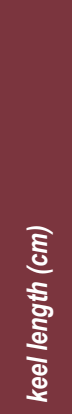 & 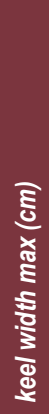 & 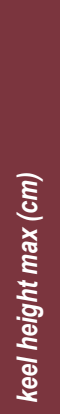 & 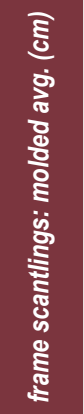 & 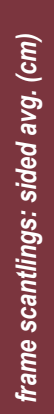 & 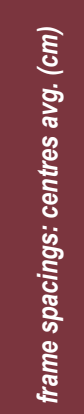 \\
\hline Blackfriars 4 & 3 & & $30-40$ & & & $C$ & & & & & & $\mathrm{~F}$ & & 42 & 10 & 13 & & \\
\hline Ramslandsvåg & 20 & & & & & C & & & & & & $\mathrm{T}$ & & 15 & & & & \\
\hline Bankside & 3 & $14-28$ & $13-19$ & $\mathrm{H}$ & $\mathrm{H}$ & C & $5-6$ & & $17 / 23$ & & & & & & & & & \\
\hline Newport & 2 & 38 & 50 & WH & WH & $C$ & 12 & $36 \times 43$ & 30 & & & V & & 27 & 24 & 21 & 26 & 37 \\
\hline B 36 & 5 & & & M & & C & $6-7$ & $28 \times 32$ & & & & B & & & & 12 & 9 & $55-70$ \\
\hline Sørenga 9 & 16 & 13 & $20-36$ & $\mathrm{H}$ & & C & & & $21 / 30$ & & & & & & & & 9 & $52-66$ \\
\hline $\begin{array}{l}\text { Hays W-Morgans } \\
\text { Lane }\end{array}$ & 3 & $18-29$ & $24-25$ & $\mathrm{H}$ & & & $4-5$ & & $18-26$ & & & & & & & & & \\
\hline Sørenga 10 & 16 & $7-12$ & 52 & W & & & $4-7$ & & $23-25$ & & & $\mathrm{~T}$ & & 22 & 9.5 & & 8 & $90-100$ \\
\hline Sørenga 8 & 16 & $22-25$ & & WH & & C & & & $23-30$ & v & 14.7 & $\mathrm{~T}$ & & & & 10 & $\begin{array}{l}10- \\
12\end{array}$ & $50-65$ \\
\hline Hays Wharf & 3 & & & & & & & & 36 & & & & & & & & & \\
\hline E 159 & 5 & & & M & & CT & & & & & & B & & & & & & \\
\hline U34 & 5 & & & MS & & CT & & & & & & B & 2550 & 25 & 42 & $16-35$ & $\begin{array}{l}18- \\
34\end{array}$ & $45-52$ \\
\hline M11 & 5 & & & M & & CT & & & & & & $\mathrm{F}$ & & & & & & \\
\hline $\mathrm{O} 28$ & 5 & & & $\mathrm{HM}$ & & C & & & & & & B & & & & & & \\
\hline Hays W-B Factory & 3 & & 36 & $H$ & & C & 7 & & & & & & & & & & & 133 \\
\hline J137 & 5 & & & $\mathrm{H}$ & & & & & & & & B & & & & & & \\
\hline
\end{tabular}

although it is unknown whether this included timber. The fact that the timber provenance of the Beluga ship was Daugavian may provide a decisive cue, as it indicates that the builders of the Beluga ship had a different access to a timber source. Livonian - that is, Daugavian - forest products were traded at least since the early fourteenth century at the Scania trade fair - in Skanör and Falsterbo - which was primarily renowned as herring market. ${ }^{62}$ This would have been an important node, where Scandinavians and especially Danes would have had access to goods exported via Riga. The amalgation of a Scandinavian-style construction and wainscot of Daugavian origin would point to an alternative timber market, which sets the Beluga ship apart from the main -Vistulian - timber trade network of the time.

Despite the distinctive access to a timber source, the Beluga ship reflects a general trend in the use of imported timber. According to a statistical evaluation of wrecks in the area of medieval Denmark, the archaeological record seems to indicate that before $c$. 1355 most vessels were built of timber from local or adjacent regions, but that a shift occured thereafter, which prompted the provenances to be more internationally composed, reflecting the increase of timber trade. ${ }^{63}$ Moreover, traditionally lapstrake constructions like the Beluga ship prevailed in the eastern part of medieval Denmark, ${ }^{64}$ which included Scania. This is possibly of significance with regard to the abovementioned Livonian timber trade.

A terminus post quem of 1396 deduced for the Beluga ship (Fig. 3) would be consistent with this general trend, if indeed the ship was of Danish origin. After the Peace of Stralsund of 1370 was signed, the City of Riga granted Danish merchants the same rights of trade they enjoyed before the war with the Hanse. ${ }^{65}$

The fact that the Beluga ship appears to have been not only scrapped in Bremen, but also repaired locally with timber from the Weser lowlands, suggests that if it was a Scandinavian vessel, it regularly frequented the port of Bremen. But Danes were certainly not the only Scandinavians with whom Bremen maintained trading relations. From 1279, Bremen merchants enjoyed trade privileges in Norway. The ties between Bremeners and Norwegians were in fact so close, that Bremen usually 
sided with Norway when the Hanse pushed sanctions against the Kingdom of Norway, and continued trade even when other Hanseatic cities blockaded Norwegian ports. As was recently pointed out, Bremen's status within the Hanse is questionable as there are actually no indications for Bremen's participation in the Diet until 1358. ${ }^{66}$ Bremen merchants concluded their trade relation with Norway independently from the rest of other Hanse cities, as confirmed by a treaty dating to $1321 .{ }^{67}$ And in 1346 the Norwegian king granted that Bremen merchants should enjoy the same rights as that of the Hanseatic community, demonstrating the preeminent importance of Bremeners, being preceived not part of the latter, but as a distinctive group. ${ }^{68}$

Could the Beluga ship also be interpreted as a legacy of the longstanding ties between Bremeners and Norwegians, and could the Beluga ship have been of Norwegian rather than Danish origin? On archaeological grounds, the construction features of the Beluga ship have many similarities to Norwegian finds, particularly regarding the wool caulking, or the use of radially cleft planks. Even the late medieval assemblage from the Bryggen excavation in Bergen indicates that no significant changes in the tools or wood-working techniques have occured since the Viking Age, where almost only radially cleft planks were used. The earliest water-powered saw-mills were built in Norway as late as 1520 to $1550 .{ }^{69}$ On historical grounds, however, there is no documentary evidence to suggest that Baltic timber was imported to Norway in that period. ${ }^{70}$

While the absence of concrete evidence does certainly not preclude the possibility that any such trade may have occured, it would have been an exception rather than the rule. Judging from the construction, or what is left of it, ${ }^{71}$ it would have possessed good sailing qualities, which would have been important for crossing the Kattegat and whenever onshore winds turned the Jutland coast - which was poor in natural harbours and shelter - into a dangerous lee shore. To go even a step further, one could raise the question whether Bremeners or other Hanseatic merchants could have obtained vessels from Scandinavian shipwrights for their own use? Although depictions of ships on Hanseatic town seals consistently represent vessels similar to the 'Bremen Cog', there is no reason to believe that the towns' self-representation matched up with common practice. They could have relied on the local craft for lighter traffic, which would have been most suited to its respective environment. This would explain why ship-timbers associated with the Hanseatic tradition - as typified by the 'Bremen Cog' - were totally absent from the rich maritime archaeological material recovered from the Tyskebryggen excavations in Bergen, ${ }^{72}$ even though Bergen was one of the Kontors of the Hanse. The recent recognition that Avaldsnes served not only as anchorage but also had some basic infrastructure for the storage of merchandise could point to a place of transshipment - a roadstead easily accessible for sturdy and large seagoing vessels like the Avaldsnes ship, where cargo was unloaded on to smaller, more maneouverable vessels, which could navigate in the narrow fjords to Bergen with greater ease. The fact that the Beluga ship was discovered in the city of Bremen at a time, when larger vessels were bound to anchor in the roadsteads in the Weser estuary, may be an indication that the Beluga ship operated as part of Bremen's lighter traffic, ${ }^{73}$ a possibility that will be explored in the following section.

\section{Between shoals and pirates: embedding the Beluga ship into the local historical context of Bremen}

In spite of its 'foreign' Scandinavian construction, the Beluga ship may not have been an uncommon sight to contemporaries outside of Scandinavia (Fig. 5). There are by now sufficient examples to indicate that the clinker-technique practised by Scandinavian shipwrights was not unknown at the southern North Sea coast, with corresponding finds from the Netherlands. ${ }^{74}$ It was even suggested that there could be a link between Frisian and Scandinavian shipbuilders with reference to clusters of clinkernails from early medieval Frisian find contexts from Wijnaldum in Oostergo, Beetgum-Besseburen and Oosterbeintum..$^{75}$ Although finds of clinker-nails are sparse, they are continously present throughout the medieval period in Frisian populated areas, ${ }^{76}$ which gave rise to the assumption that a technology transfer may have occured as early as the fourth or early fifth century through visiting Scandinavian craftsmen. ${ }^{77}$ However, this was rightly called into question on the basis that the absence of rove blanks in the finds collection does not provide any tangible proof that the clinker-method was practised in this area. ${ }^{78}$ Visiting Scandinavian vessel could have simply been scrapped here. Nonetheless, clinker finds from the southern North Sea litoral are not restricted to Frisian areas, but also found in thirteenth-century urban contexts from Vlaardingen, Tiel and Rotterdam, ${ }^{79}$ Stade ${ }^{80}$ and the fourteenth- to fifteenth-century finds context from 


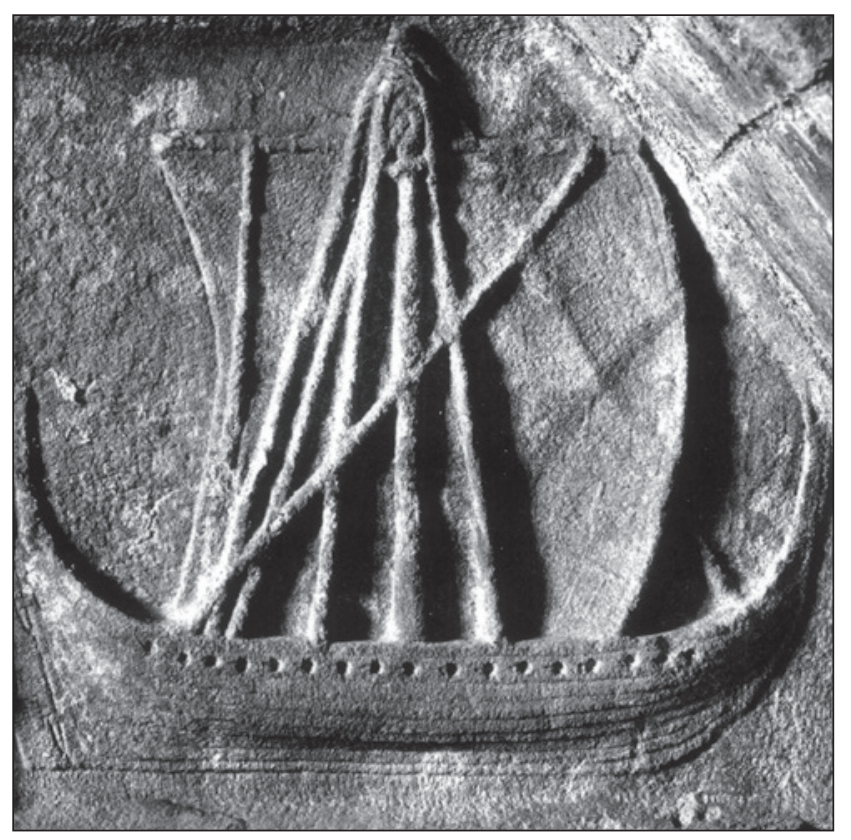

Fig. 5. A depiction of a clinker-built birlinn with seventeen oar-ports on a gravestone slab of 1523 in Harris, Scotland. These types of vessels had a Norse ancestry and were widespread in the Hebrides and west Highlands. Aside from the compellingly similar stem shape and deadrise, as could be inferred from the strake contours, this illustration was not included to suggest any direct correlation to the Beluga Ship, but to highlight that old-fashioned Scandinavian-looking vessels were neither exclusive to Scandinavia, nor to the Viking Age (Crumlin-Pedersen 2010, fig. 3.41).

Harburg, including rove blanks, ${ }^{81}$ so it can be asserted that such vessels were at least repaired locally.

This may be also assumed in the case of the Beluga ship, as the upper strakes were amended with planks hewn in the second half of the fifteenth century in the Weser lowland (Fig. 6), which was a predominantly Frisian populated area. The fact that it was not only scrapped in Bremen, but apparently also repaired with timber coming from a source nearby, suggests that the vessel operated in this region for some time. Its light construction would have made it suitable to be operated not only under sails, but also under oars, and there are indications for such vessels in Hanseatic towns. ${ }^{82}$ The Beluga ship might have been identified by a range of names by contemporaries, for instance as bardze - which would have been a light raider which could be sailed and rowed. ${ }^{83}$ Vessels operating under oars are mentioned in documents from both English and Hanseatic ports. ${ }^{84}$ Likewise schnigge or snycke, which appears to be the German equivalent to the Scandinavian snekkja and used by Hanseatic towns for safeguarding its waterways, such as in Danzig in $1462 .{ }^{85}$ The possible use for such 'light raiders' becomes clear when illustrating the geo-political circumstances of the time. The Beluga ship's repair phase around/after 1446 from local wood from the Weser lowland coincides with a period in which the city of Bremen lost its control of this very area. Around 1400 navigation on River Weser was threatened: an increased fluvial sedimentation led to the silting up of parts of the river, which posed difficulties to mariners, as they had to avoid numerous new shoals as navigation channels became narrower. These problems are reflected by the city's well-documented effort to safeguard navigation by claiming the right to set navigation marks and buoys in the Lower Weser in $1410,{ }^{86}$ a duty that was soon thereafter - in 1426 assigned to its merchant community. ${ }^{87}$ Large ships were increasingly required to anchor in the roadstead at the Weser estuary - probably near Blexen ${ }^{88}$ - and transship

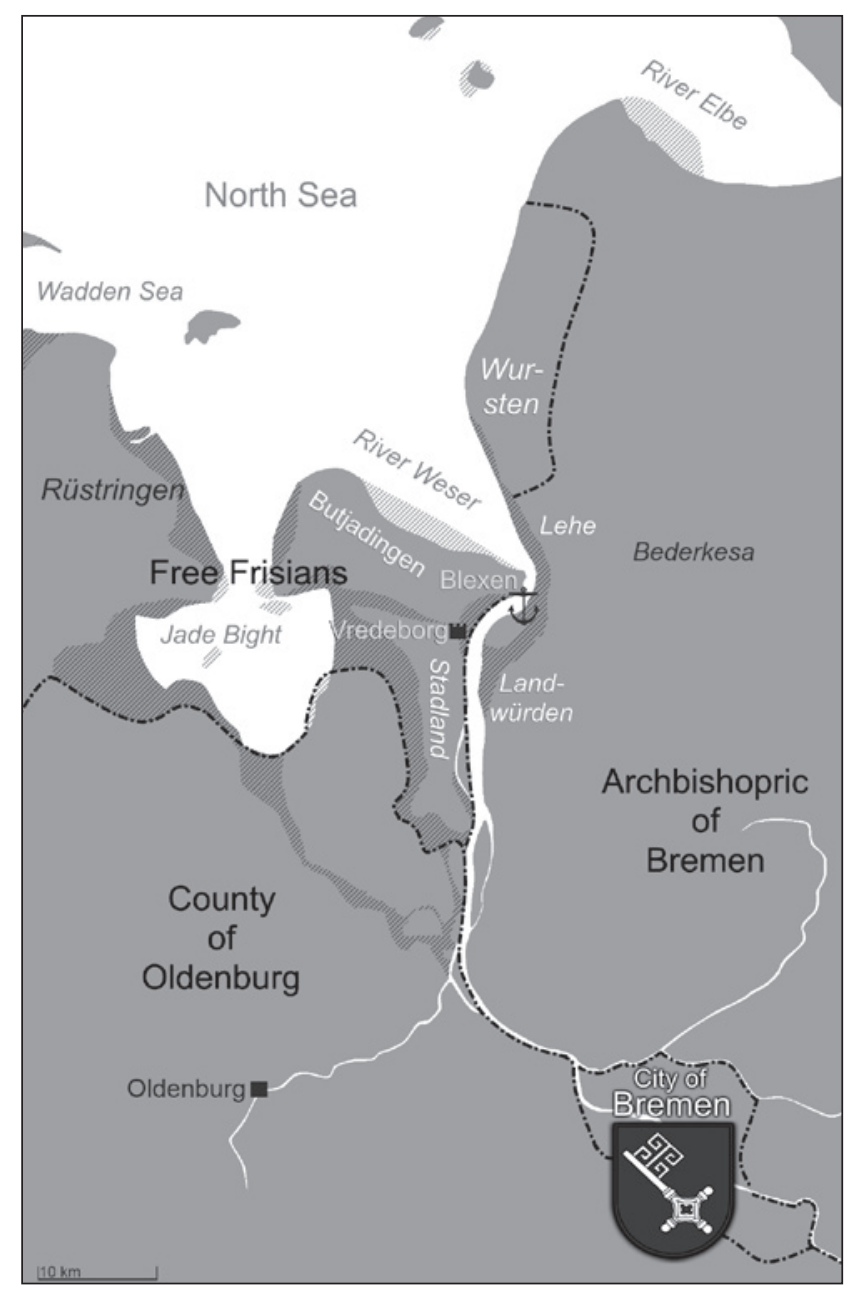

Fig. 6. The local geo-political context of Bremen and the Frisian populated Lower Weser region. The hachured areas roughly indicate the river course and coastline of the fifteenth century (illustration: Daniel Zwick, based on Behre 2013, fig. 4 and Hill 2004, fig. 17). 
their commodities via lighters to Bremen. ${ }^{89}$ This, on the other hand, collided with the political destabilization of the Frisian-populated Weser estuarine region. Since the second half of the fourteenth century, East Frisia had been characterized by the rise of Frisian chieftain dynasties, which were in conflict amongst each other and harboured quite literally the Victual Brothers pirates expelled 1398 from the island of Gotland - who were welcomed and redirected as 'marine mercenaries' into the local Frisian conflicts. ${ }^{90}$ This was perceived as such a threat to Bremen's mercantile interests, that the city sought to exert direct territorial control over the Lower Weser area in a period from roughly 1400 to 1425 , by assuming sovereignty over the Frisian land of Butjadingen - sanctioned by King Sigismund -, (...) by forming tight alliances with the Frisian territories Stadland, Lehe, Landwürden and Wursten ${ }^{91}$ to saveguard River Weser as libera et regia strata - as a free and royal 'road'. ${ }^{92}$ However, Bremen's regional supremacy in the lower Weser region was short-lived when Count Christian of Oldenburg in alliance with the chieftain of Rüstringen, Edo Wiemken, and Butjadingen rebels destroyed the Bremen-held castle of Vredeborg in $1425,{ }^{93}$ which had protected its roadstead.

The lower Weser provenenace of the repair of around/ after 1446 indicates that the Beluga ship may have been active in lighter traffic or even used to either saveguard or obstruct navigation by one side or the other in this period of political instability.

\section{Conclusion}

In this paper the question was raised - possibly for the first time - whether there is a correlation between late medieval clinker-built vessels in the North Sea area and Baltic timber imports. The evaluation has shown that there is indeed positive evidence to support the assumption, but it has also shown that the presently available data is not sufficient to establish more detailed constructional correlations. It could be, however, anticipated that different categories of import timber could be identified archaeologically by collecting statistical data on plank lengths. In the particular case of the Beluga ship where only the bow section has survived, this would have made little statistical sense, as the longest planks are usually used in the midship section. Nontheless, there is a latent potential for a statistical evaluation, as has been demonstrated in the few known cases where planks were part of the cargo assemblage, which conversion and dimensions seem to match with timbers listed as export items (Table 3).
While only general assertions could be made on the correlation between clinker vessels and timber imports, one thing seems to be clear: the stereotypical impression of what constituted shipping in a Hanseatic port has to be revised and is certainly not adequately represented by ships like the 'Bremen Cog' alone. ${ }^{94}$ While this volume highlights the far-flung Hanseatic trade network in North-Western Europe and thereby opens up a new chapter of Hanse archaeology, the findings of this paper suggest that the trade network in the 'Hanseatic sphere' was not a one-way street for a predominantly Low German mercantile and cultural influence, but that counter-influences will have occured too. The finding of the Beluga ship may be testiment to Danes, Norwegians or other foreigners conducting trade in a Hanseatic port, or possibly Bremen merchants or Frisian raiders who preferred Scandinavian-built vessels. The great manoeuvrability of such lightly constructed vessels with little draught would have not only been preferable in winding Norwegian fjords or the Frisian and Danish Wadden Sea with its many islands and shoals, but arguably also in the swiftly changing fluvial landscape of the Weser, in which navigability had decreased dramatically in the course of the fifteenth century.

\section{Acknowledgements}

This chapter is part of my cumulative dissertation 'Maritime Logistics in the Age of the Northern Crusades' submitted at the University of Kiel in 2016. I am indebted to Dieter Bishop for entrusting me with the recording, study and publication of this shipwreck. Damian Goodburn and Anton Englert gave me inspiring feedback and advice, and thereby contributed significantly to the discussion. The latter and Fred Hocker made some very important remarks on the correct use of terminology as devised by the Viking Ship Museum Roskilde, which helped this author to align this paper to what ought to become a common standard within the field of maritime archaeology. Thanks are also due to Xenius Nielsen, Toby Jones, Gustav Milne, Nigel Nayling, Waldemar Ossowski, Alice Overmeer, Staffan von Arbin and Maris Zunde for making available manuscripts prior to publishing or for sending me copies of hard-to-get publications, and - in many cases - for providing additional details not mentioned in the published work. For further personal communications, I thank Niels Bonde, Karl-Uwe Heußner, Peter Marsden and Andreas Schäfer. Last not least, I would like to thank Natascha Mehler, Endre Elvestad and 
Mark Gardiner for inviting me to the highly interesting conference to Avaldsnes, Norway, to which it was a great pleasure to contribute this paper.

\section{Endnotes}

${ }^{1}$ Excavation no. 230 'Altstadt Teerhof BA1', feature no. 36 'Beluga ship'.

2 The 'Nordic' or 'Scandinavian' shipbuilding tradition should not be understood in a strictly ethnic sense, as it could also occur outside of the Scandinavian world ( $c f$. Crumlin-Pedersen 2004, 43).

${ }^{3}$ In this article only a brief summary of the technical details is provided. The construction method is discussed in more detail in Zwick 2010, Zwick 2012 and Zwick 2017.

${ }^{4}$ Also known as luting, describing a procedure by which the caulking material is inserted before assembling the planks, rather than being driven in afterwards.

${ }^{5}$ Radial cleaving occurs along the grain, which is usually not as even as sawn cuts. Thus, edge thicknesses vary slightly in such planks and are more difficult to waterproof when fastened edge to edge (Coates 1977, 223).

${ }^{6}$ Steen 2012, 50.

${ }^{7}$ Bill 1997, tab. 1.

${ }^{8}$ E.g. Auer and Maarleveld 2013, 15; Thowsen 1965, 45.

${ }^{9}$ A garboard is the first strake, i.e. all planks connected to the keel, and a rabbet is a notch to receive such a component (here: the plank edges of the garboard strake).

${ }^{10}$ The deadrise angle describes the shape of the underwater hull, e.g. flat-bottomed river barges have no deadrise and seagoing vessels with tapering fore-and aft sections and a S-shaped cross-section usually have great deadrise angles.

${ }^{11}$ The absence of a keel rabbet can be also attributed to the tapering end of the bow section. A rabbet could have been present in the unpreserved part of the keel at midship section, but this would imply that the Beluga ship was considerably greater in length than the surviving fragment.

${ }^{12}$ No matches were found with the master chronologies, so the dendro laboratory Preßler was consulted, which specialized in local wood (Karl-Uwe Heußner, pers. comm. 1.4.2009).

${ }^{13}$ The average number of sapwood rings in southern Finland (closest proxy to the Baltic region where such data is available) is 13.85 according to an unpublished report by Keith Briffa (Haneca et al. 2009, 5). This average is also comparable to present-day Poland, where oak trees have an average of 15 sapwood rings on average; 9-24 in the $90 \%$ confidence interval (Ważny 1990).

${ }^{14}$ Although 14 years appears very specific, it should not be over-interpreted, as it is in itself only a proxy for the average number of tree-rings in the sapwood, which could have been considerably greater given that no sapwoodhartwood line was determined. Sapwood rings could vary between 4 to over 50 rings ( $c f$. Heußner 1999, 524).

15 The conversion technique is often regarded as decisive criteria for establishing whether a vessel was built in a modern or traditional style. Sawing is regarded as modern and cleaving as traditional (cf. Bill 2009b, 433). Scandinavians were already making use of the more modern sawing technique since at least the twelfth century, while the radial cleaving of planks is essentially Viking Age technology. The term 'antiquated' was put into inverted commas, because this technique was by no means outdated, as it had several advantages, as will be stressed in the following section.

${ }^{16}$ Cf. Ważny 2002.

${ }^{17}$ Cf. Zunde 1998/99.

${ }^{18}$ McGrail 1998, 37.

${ }^{19}$ Goodburn 2003, 293.

${ }^{20}$ Lahn 1992, 44f.

${ }^{21}$ Bill 2009b, 433.

${ }^{22}$ Cf. McGrail 1993, 11 and 19ff.

${ }^{23}$ Elsewhere also named as Dock Islands 3.

${ }^{24}$ Nielsen 2014, 111.

${ }^{25}$ L'Hour and Veyrat 1994, 170.

${ }^{26}$ Tinniswood 1949, 281.

27 Timber provenances are often obfuscated by terminology. 'Baltic timber' or 'Baltic timber trade' is often used synonymously with the Baltic Sea rather the Baltic region, meaning that 'Baltic timber' could originate from locations other than the Baltic region, such as Poland. Some authors imply a not closely defined Baltic Sea origin when they refer to 'Baltic' timber, so it can just as well include the southern Baltic Sea coast, despite it is outside of the Baltic region. Some other authors speak of a 'Polish provenance' which may include a regional bias too, as they might refer to locations in present-day Poland, like the Duchy of Pomeralia, or the towns of Danzig/Gdańsk or Elbing/Elblacg, which used to be either independent from Poland or part of the territory controlled by the Teutonic Order. This denomination could be mixed up with timber that was actually hewn in the Poland of the Middle Ages, and floated down the Vistula River to Danzig, then under the rule of the Teutonic Order (1308-1454), as Polish merchants engaged in timber trade with the Teutonic Order on a great scale, as particularly highlighted by a treaty concluded in 1343 and by an armistice of 1391, in which Polish merchants were granted the right to engage in trade with Prussia 'according to custom' with the export of their commodities via Danzig ( $c f$. Ważny and Eckstein 1987, 510). Therefore, some of the provenances taken from other reports have to be regarded with scepticism, as the respective authors have not elucidated their use of the term 'Baltic' or 'Polish'. To simplify matters, it is suggested here to introduce 'Vistulian' (the Vistula River basin, including Polish, Prussian, Pomeranian and Lithuanian provenances) and 'Daugavian' (the Daugava River basin, including the Baltic region, specifically Latvia or the historical province of Livonia, and Russia) as general terms of origin. 'Baltic timber trade' is kept as a generic term to indicate all timber trade from the Baltic Sea.

${ }^{28}$ Vlierman 1996, 111ff.; van de Moortel 2011, 95.

${ }^{29}$ Marsden 1996, 117ff. and 188; 'Baltic' is used here in its unspecified sense, meaning timber from the Baltic Sea rather than the Baltic region - pers. comm., Peter Marsden (26.3.2014).

${ }^{30}$ Haneca et al. 2005, 262.

${ }^{31}$ The decisive hint that these galleys were clinker-built with rivetted nails is given by the remark that the pichepotte (pitch pot) must be kept hot at the insertion of each strake, indicating inlaid-caulking (luting), and 
moreover the mention of clenchatores (clenchers) and tenenties contra, clenchatores (holders), which describes the two workers needed for rivetting planks together ( $c f$. Tinniswood 1949, 281).

${ }^{32}$ Ibid., 282.

${ }^{33}$ Wildwood boards were, however, not imported in greater lengths as a general rule. English finds indicate that longdistance trade boards were of relatively short dimensions (Damian Goodburn, pers. comm. 28.04.2014).

${ }^{34}$ Ważny and Eckstein 1987.

35 Zunde 1998/99.

36 Kapfenberger 2003, 20.

37 Ibid, 73.

${ }^{38}$ HR I, 2, no. 329.

39 Dollinger 1998, 290.

${ }^{40}$ Kapfenberger 2003, 56.

${ }^{41}$ Norway's dependence on annual grain imports led to Hanseatic merchants gaining control of the Norwegian export trade (Hammel-Kiesow 2002, 74), thus the great number of wrecked cargo-carriers in this region built of Vistulian timber is not surprising.

${ }^{42}$ Sauer 1996, 160.

${ }^{43}$ Goodburn 2003.

${ }_{44}$ Ellmers 2006, 74.

${ }^{45}$ Haneca et al. 2005, 262.

46 Ellmers 2006, 75.

47 The term wainscot (German Wagenschoß or Wagenschott) might not have applied to planks or boards before 1700 , but to beams, as pointed out by Kapfenberger 2003, 24.

${ }^{48}$ In a mid-nineteenth-century source (cited by Kapfenberger 2003, 24) wainscot was defined as being between 10 to 18 feet in length (3.14-5.65 m ) and cleft into four parts (richtspaltig, i.e. cleft at a right angle). The author of the source notes that the English refer to these quartered logs as wainscot-logs, but that locally - i.e. the Danzig area - smaller dielen cleft from the wainscot-logs are called wainscot too, with widths to about 10 zoll, i.e. $26.2 \mathrm{~cm}$. This may indicate that wainscot was exported to England as a semi-product, and not as ready-made planks as found in the wrecks of Skjernøysund, Gdansk W5 and Skaftö. $26.2 \mathrm{~cm}$ is close to the average widths observed in group 2.

49 Auer and Maarleveld 2013, 13, 19.

${ }^{50}$ Zwick 2010, 69f.

51 Bill 1994, 60.

${ }^{52}$ However, caulking or luting material generically sumarised under the category 'hair' may in fact be also wool, as differences between animal species can be only made when the material is well preserved.

53 Bill 2009a, 256.

${ }^{54}$ Marsden 1996, 107ff.; see also Goodburn 2003.

55 Marsden 1996, 55ff.

${ }^{56}$ Christensen 1985, 202. The fact that the two groups do not match up perfectly can be probably explained by the practice of measuring frame intervals from centre to centre, while the gaps between the frames would be slightly smaller.

57 Ejstrud and Maarleveld 2007, 135.

58 Jahnke 2006, 88.

${ }^{59}$ Fritzbøger 2004, 110.

${ }^{60}$ Pāvulāne 1975, 46; Zunde 1998/99, 121.

${ }_{61}$ Madsen 1999, 200; Madsen 2000, 255.
62 Tossavainen 1994, $23 \mathrm{f}$.

${ }^{63}$ Bill 2009b, 430.

${ }^{64}$ Ibid., 435.

${ }_{65}$ Olesen 2005, 187.

${ }^{66}$ Elmshäuser 2003, $212 \mathrm{f}$.

${ }^{67}$ BUB II, no. 217.

${ }^{68}$ BUB II, nos 544-546.

${ }^{69}$ Christensen 1985, 213.

${ }^{70}$ Cited after Alopaeus and Elvestad 2004, 80.

71 This specifically refers to the great deadrise angle, which would have increased the lateral plane, counteracting the side drift on clause-hauled courses.

${ }^{72}$ Christensen 1989, 18.

${ }^{73}$ Large sturdy seagoing vessels, which could not easily access rivers, were often bound to anchor in a sheltered roadstead at some distance to the cities and were loaded and unloaded by lighters (often also referred to as 'bordings' in written sources), which operated between the roadsteds and the city quays.

${ }^{74}$ Cf. van Holk 2003.

75 Reinders and Aalders 2007, 115.

${ }^{76}$ Ibid, 117.

77 Ibid., 119.

78 van de Moortel 2011, 97.

${ }^{79}$ Cited after Reinders and Aalders 2007.

${ }^{80}$ Andreas Schäfer, pers. comm.

${ }^{81}$ Several rivets were catalogued by this author who was researching the maritime find collection from the Schloßstraße-excavation in Harburg - Hamburg's southernmost district south of the Elbe, which used to be historically independent from Hamburg. At least two rivets appear to be blanks, providing concrete evidence that rivetting occured locally.

${ }^{82}$ Despite there are no archaeological remains of a plank with oar-holes, the Beluga ship would have been predestined to be rowed, which also explains its find-spot some $50 \mathrm{~km}$ up the river at a time when most sailing vessels would have anchored at the Weser estuary and transshipped its cargo via lighter traffic to and from Bremen.

${ }^{83}$ Heinsius 1986, 209.

${ }^{84}$ Kiesselbach 1901, 89; Tinniswood 1949, 285.

${ }^{85}$ HUB VIII, no. 1150. The Scandinavian etymological origin is particularly thought-provoking with regard to the wreck's Scandinavian means of construction.

${ }^{86}$ BUB IV, no. 406.

${ }^{87}$ BUB V, no. 297.

${ }^{88}$ Weidinger 2002, 127.

${ }^{89}$ Hill 2004, 266.

90 Although it is argued that Bremen too maintained mutually beneficial links with the pirates - serving as market for robbed goods, or supporting Bremen's war efforts against the chieftain of Rüstringen Edo Wiemken around 1400 - this must have destabilised the entire region and threatened trade (Elmshäuser 2003, 227).

${ }^{91}$ HUB V, no. 701; Schwarzwälder 1994, 4.

92 Hill 2004, 273f.

93 Ibid., 301ff.

${ }^{94}$ Cf. Zwick 2014, 61ff.

\section{Endnotes Table 2:}

${ }^{1}$ The information gained from the group of ships with isolated planking needs to be regarded with caution. Although belonging into the same context, the planks 
were recorded as isolated finds and may have belonged to different constructions. Some of the details are not representative, as many observations stem from infrequent sampling. Summarizing the observed criteria is not straightforward and were made at the author's discretion, by trying to isolate typical measurements either based on representativity or state of preservation. Some less representative measurements, e.g. in cases of fragmented pieces, are ignored as not to distract from general trends. Only dated material is taken into account.

${ }^{2}$ Kingston: Goodburn 1991, 108ff.; TYT98: Goodburn 200; Vestre Skarsholm: Bill 1997, 202f.; Halmstad: Bill 1997, 171f.; Sørenga 3: Nævestad 1998, 173ff.; Bryggen strakes numbers 90151 and 90152 from one wreck: Christensen 1985, 93, 99; Roskilde Havn 1: Bill 1997, 186f., Bill 2009b, 434; Hundevika: Teisen 1994, Nævestad 1998, 200ff.; Hays-Symonds Wharf 1988 site context: 141-168, 175-164, 194-136, 196-120: Marsden 1996, 188f.; Southwark Abbots Lane context 185/64, 195/74: cf. Marsden 1996, 107ff., 188ff.; Sandwich: Milne 2004; Sørenga 1: Nævestad 1998, 171ff.; Sørenga 2: Nævestad 1998, 172ff.; Hays Wharf-Abbots Lane 1987 site context: 205-86, 187-66, 185-64, 195-74: Marsden 1996, 188f.; Hays Wharf-Gun and Shot Wharf 1988 site context 44953-158/60: Marsden 1996, 188f.; Isegran: Nævestad 1998, 161ff.; Sundekilen: Nævestad 1998, 178ff.; Kerteminde 1: Bill 1997, 174f.; Bøle: Daly and Nymoen 2007, Nævestad 1998, 180ff.; Skjernøysund 3: Auer and Maarleveld 2013; Avaldsnes: Alopeus and Elvestad 2004; Beluga: Zwick 2010, Zwick 2017; Blackfriars 3: Marsden 1996, 55ff.; Dokøen 2: Gøthche and Høst-Madsen 2001, 32ff.; Ny Hellesund 2: Nævestad 1998, 190ff.; Århus Å: Bill 1997, 203f.; Dokøen 4: Gøthche and Høst-Madsen 2001, 34; Foldrøy: Thowsen 1965; G35: Overmeer 2008, 51; Overmeer forthcoming; Dokøen 3: Nielsen 2014; Skaftö: von Arbin 2012, von Arbin 2014; Selør 4: Nævestad 1998, 195ff.; Aber Wrac'h: L'Hour and Veyrat 1994; Vedby Hage: Myrhøj 2000; Århus 1: Larsen et al. 2011; Århus 4: Larsen et al. 2011; Århus 5: Larsen et al. 2011; Blackfriars 4: Marsden 1996, 105; Ramslandsvåg: Nævestad 1998, 191ff.; Bankside 37-46, 1987; Revet 21: Marsden 1996, 192f.; Newport: Nayling and Jones 2014, Nayling and Susperregi 2014; B 36: Overmeer 2009; Sørenga 9: Fawsitt 2012a; Hays Wharf-Morgans Lane 1987, site context: 735-123, 659-35, 625-13, 632/4-32/4, 837-50: Marsden 1996, 192f.; Sørenga 10: Fawsitt 2012b; Sørenga 8: Steen 2012; Hays Wharf: Goodburn 1991, 111; E 159: Overmeer 2006; U34: van Holk 2003, Overmeer 2006, 66ff.; M11: Overmeer 2008, 51; O28: Overmeer 2008, 51; Hays Wharf-Butter Factory South 1988 site context: 158-150/4, 118-49: Marsden 1996, 194f.; J137: Overmeer 2008, 51.

\section{Endnotes Table 3:}

${ }^{3}$ Skjernøysund 3: Auer and Maarleveld 2013, 27ff.; Gdansk W5: Litwin 1985, 46; Krąpiec and Krąpiec 2014, 147; Ważny 2001, cited in Eckstein and Wrobel 2007, 13f.; Skaftö: von Arbin 2014, 34.

${ }^{4}$ These were made on own estimates on the basis of the data provided by the excavators, which unfortunately lacks the information which measurements refer to well-preserved planks and which to mere fragments, $c f$. Auer and Maarleveld 2013, tab. 1, p. 29.

\section{Endnotes Table 4:}

${ }^{5}$ For referenes see footnote 2 , of table 2 .

${ }^{6}$ The shape of the keel can vary, depending on whether the cross-section sample is taken from the midship or the fore/aftership section. This presents yet another problem for a comparative evaluation, as most wrecks are only partially preserved.

\section{References}

Alopaeus, H. and Elvestad, E. 2004. Avaldsnesskipet - et 'nordisk' skip fra Polen?, in T. Torfæus, Mellom Vinland og 'Ringenes herre', Karmøyseminaret 2004, 73-86. Karmøy: Karmøy Kommune.

von Arbin, S. 2012. A fifteenh-century bulk carrier, wrecked off Skaftö, Western Sweden, in N. Günsenin (ed.), Between Continents (Proceedings of the Twelfth Symposium on Boat and Ship Archaeology, Istanbul 2009), 67-74. Istanbul: Ege Yayınları.

von Arbin, S. 2014. Skaftövraket - ett senmedeltida handelsfartyg. Uddevalla: Bohuslän Museum.

Auer, J. and Maarleveld, T. 2013. Skjernøysund Wreck 3: Fieldwork Report 2011 (Esbjerg Maritime Archaeology Reports 5). Esbjerg: Syddansk Universitet.

Behre, K.-E. 2013. Die Meeresspiegelschwankungen der vergangenen Jahrtausende und deren Bedeutung für das Siedlungsgeschehen an der deutschen Nordseeküste / The sea-level fluctuations over past millennia and their impact on the settlement process along the German North Sea coast. Siedlungs- und Küstenforschung im südlichen Nordseegebiet/Settlement and Coastal Research in the Southern North Sea Region 36, 13-30.

Bill, J. 1994. Iron nails in Iron Age and medieval shipbuilding, in C. Westerdahl (ed.), Crossroads in Ancient Shipbuilding (Proceedings of the Sixth International Symposium on Boat and Ship Archaeology), 55-64. Roskilde: Vikingeskibsmuseet.

Bill, J. 1997. Small Scale Seafaring in Danish Waters AD 1000-1600. Unpublished PhD thesis, Copenhagen: Københavns Universitet.

Bill, J. 2009a. Zwischen Kogge und Kraweel. Traditioneller Kleinschiffbau in Südskandinavien in einer Zeit der Wende, in B. Scholkmann, C. Vossler and M. Wolf (eds), Zwischen Tradition und Wandel. Archäologie des 15. und 16. Jahrhunderts, 251-260. Büchenbach: Verlag Dr. Faustus.

Bill, J. 2009b. From Nordic to north European - application of multiple correspondence analysis in the study of changes in Danish shipbuilding A.D. 900-1600, in R. Bockius (ed.), Between the Seas. Transfer and Exchange in Nautical Technology (Proceedings of the Eleventh International Symposium on Boat and Ship Archaeology), 429-438. Mainz: Römisch-Germanisches Zentralmuseum.

Christensen, A. E. 1985. Boat finds from Bryggen, in A. E. Herteig, The Archaeological Excavations at Bryggen, 'The German Wharf', in Bergen 1955-68 (Bryggen Papers Main Series I), 47-278. Bergen: Universitetsforlaget.

Christensen, A. E. 1989. Hanseatic and Nordic ships in medieval trade. Were the cogs better vessels?, in 
C. Villain-Gandossi, S. Busuttil and P. Adam (eds), Medieval Ships and the Birth of Technological Societies, 17-24. Valetta: University of Malta.

Coates, J. F. 1977. Hypothetical reconstructions and the naval rchitect, in S. McGrail (ed.) Sources and Techniques in Boat Archaeology (British Archaeological Reports 29), 215-226. Oxford: British Archaeological Reports.

Crumlin-Pedersen, O. 2004. Nordic clinker construction, in F.M. Hocker and C.A. Ward (eds), The Philosophy of Shipbuilding: Conceptual Approaches to the Study of Wooden Ships, 37-63. College Station: Texas A \& M University Press.

Crumlin-Pedersen, O. 2010. Archaeology and the Sea in Scandinavia and Britain. A Personal Account (Maritime Cultures in the North 3). Roskilde: Vikingeskibsmuseet.

Daly, A. 2007. Timber, Trade and Tree-rings. A dendrological analysis of structural oak timber in northern Europe, c. AD 1000 to c. AD 1650. Unpublished PhD thesis, Esbjerg: Syddansk Universitet.

Daly, A. and Nymoen, P. 2007. The Bøle Ship, Skien, Norway - research history, dendrochronology and provenance. International Journal of Nautical Archaeology 37(1), 153-170.

Dollinger, P. 1998. Die Hanse (fifth edition). Stuttgart: Kröner.

Eckstein, D. and Wrobel, S. 2007. Dendrochronological proof of origin of historic timber - retrospect and perspectives, in K. Haneca, A. Verheyden, $\mathrm{H}$. Beekmann, H. Gärtner, G. Helle and G. Schleser (eds), TRACE - Tree Rings in Archaeology, Climatology and Ecology 5 (Proceedings of the Dendrosymposium 2006, April 20th-22nd, Tervuren, Belgium), 8-20. Jülich: Forschungszentrum Jülich $\mathrm{GmbH}$.

Ejstrud, B. and Maarleveld, T. 2007. Et middelalderligt fragtskib - marinarkæologi i Knudedybet. Sjæklen. Årbog for Fiskeri- og Søfartsmuseet, 132-141. Esbjerg: Saltvandsakvariet.

Ellmers, D. 2006. Hansischer Handel mit Schiffsbauholz. Ein Beitrag zur Wörter- und Sachen-Forschung, in H.-P. Baum, R. Leng and J. Schneider (eds), Wirtschaft, Gesellschaft, Mentalitäten im Mittelalter, 63-78. Stuttgart: Steiner.

Elmshäuser, K. 2003. Bremen und seine Kaufleute - Konflikte und Kämpfe, in G. Hoffmann and U. Schnall (eds), Die Kogge - Sternstunde der deutschen Schiffsarchäologie, 206-233. Bremerhaven and Hamburg: Convent.

Eriksen, O. H. 2001. Dendrokronologisk undersøgelse af tømmer fra skibsvrag fundet på Dokøen, København (Nationalmuseets Naturvidenskabelige Undersøgelser rapport 23/2001). Copenhagen: Nationalmuseet.

Fawsitt, S. 2012a. Rapport: Dronning Eufemiasgate Sørenga 9 (Arkeologisk Rapport 2012, 9). Oslo: Norsk Maritimt Museum.

Fawsitt, S. 2012b. Rapport: Dronning Eufemiasgate Sørenga 10 (Arkeologisk Rapport 2012, 10). Oslo: Norsk Maritimt Museum.

Fritzbøger, B. 2004. A Windfall for the Magnates: The Development of Woodland Ownership in Denmark c. 1150-1830. Odense: Syddansk Universitet.

Godal, J. B. 1995. The use of wood in boatbuilding, in O.
Olsen, J. Skamby Madsen and F. Rieck (eds), Shipshape: Essays for Ole Crumlin-Pedersen, 271-282. Roskilde: Vikingeskibsmuseet.

Goodburn, D. M. 1991. New light on early ship- and boatbuilding in the London area, in G. L. Good, R. H. Jones and M. W. Ponsford (eds), Waterfront Archaeology (Proceedings of the third international conference on waterfront archaeology held at Bristol 23-26 September 1988), 105-115. London: Council for British Archaeology.

Goodburn, D. 2003. Rare fragments of a 13th century clinker galley found in London and the use of the Irish wildwoods for shipbuilding, in C. Beltrame (ed.), Boats, Ships and Shipyards (Proceedings of the Ninth International Symposium on Boat and Ship Archaeology, Venice 2000), 289-295. Oxford: Oxbow Books.

Gøthche, M. and Høst-Madsen, L. 2001. Medieval wrecks at Dock Island, Copenhagen. Maritime Archaeology Newsletter from Roskilde, Denmark 17, 28-33.

Hammel-Kiesow, R. 2002. Lübeck and the Baltic trade in bulk goods for the North Sea region 1150-1400, in L. Berggren, N. Hybel and A. Landen (eds), Cogs, Cargoes, and Commerce: Maritime Bulk Trade in Northern Europe, 1150-1400, 53-91. Toronto: Pontifical Institute of Mediaeval Studies.

Haneca, K., Ważny, T., van Acker, J., Beeckman, H. 2005. Provenancing Baltic timber from art historical objects: success and limitations. Journal of Archaeological Science 32, 261-271.

Haneca, K., Čufar, K., Beeckman, H. 2009. Oaks, tree-rings and wooden cultural heritage: a review of the main characteristics and applications of oak dendrochronology in Europe. Journal of Archaeological Science 36(1), 1-11.

Heinsius, P. 1986. Das Schiff der hansischen Frühzeit. Cologne and Vienna: Böhlau.

Heußner, K.-U. 1999. Wieviel fehlt? - Ein Beitrag zur Genauigkeit von dendrologischen Datierungen, in E. Cziesla, T. Kersting and S. Pratsch (eds), "Den Bogen spannen..." Festschrift für Bernhard Gramsch, 523-525. Weissbach: Beier and Beran.

Hill, T. 2004. Die Stadt und ihr Markt: Bremens Umlandsund Aussenbeziehungen im Mittelalter (12.-15. Jahrhundert). Stuttgart: Steiner.

van Holk, A. F. L. 2003. Clenched lap-strake boat finds from the Netherlands, between 1200 and 1600, in C. Beltrame (ed.), Boats, Ships and Shipyards (Proceedings of the ninth International Symposium on Boat and Ship Archaeology, Venice 2000), 296-305. Oxford: Oxbow Books.

Jahnke, C. 2006. Dronningens skibe for kongens flåde. Dronning Dorothea af Brandenburgs skibsbygning omkring 1486. Maritim Kontakt 28, 85-94.

Kapfenberger, D. 2003. Holz und Holzhandel in Preußen von 1399-1409. Unpublished master's thesis, Erlangen: Universität Erlangen.

Kiesselbach, T. 1901. Grundlage und Bestandteile des ältesten Hamburgischen Schiffrechts. Ein Beitrag zur Geschichte des norddeutschen Seehandels und Seerechts. Hansische Geschichtsblätter 28, 49-93.

Krąpiec, M. and Krąpiec, P. 2014. Dendrochronological analysis of the copper ship's structural timbers and 
timber cargo, in W. Ossowski (ed.), The Copper Ship - A medieval Shipwreck and its cargo/Miedziowiec - Wrak średniowiecznego statku i jego ładunek. (Badania Archeologiczne Narodowego Muzeum Morskiego w Gdańsku 2), 143-160. Gdansk: Polish Maritime Museum.

Lahn, W. 1992. Die Kogge von Bremen. Band 1: Bauteile und Bauablauf. Hamburg: Convent.

Larsen, L. K., Baittinger, C. and Bonde, N. 2011. Reused boat timbers from Aarhus. Maritime Archaeology Newsletter from Denmark 26, 21-23.

L'Hour, M. and Veyrat, E. 1994. The French medieval clinker wreck from Aber Wrac'h, in C. Westerdahl (ed.), Crossroads in Ancient Shipbuilding (Proceedings of the Sixth International Symposium on Boat and Ship Archaeology, Roskilde 1991), 165-180. Oxford: Oxbow Books.

Litwin, J. 1985. The Copper Ship of Gdansk Bay; recent discoveries from the wreck, cargo and site, in J. Heermann (ed.), Fifth International Congress of Maritime Museums Proceedings 1984, 42-49. Hamburg: Museum für Hamburgische Geschichte.

Madsen, P. K. 1999. Ribe between west and east - a North Sea harbour and its Baltic connections 700-1600, in J. Bill and B. L. Clausen (eds), Maritime Topography and the Medieval Town (Papers from the Fifth International Conference on Waterfront Archaeology in Copenhagen, 1998. PNM Series: Studies in Archaeology and History 4), 197-202. Copenhagen: Nationalmuseet.

Madsen, P. K. 2000. Ribes baltiske handelsforbindelser, in P. Ingesman and B. Poulsen (eds), Danmark og Europa $i$ senmiddelalderen, 243-263. Aarhus: Aarhus Universitetsforlag.

Marsden, P. 1996. Ships of the Port of London (English Heritage Archaeological Report 5). London: English Heritage.

McGrail, S. 1993. Medieval Boat and Ship Timbers from Dublin. Dublin: Royal Irish Academy.

McGrail, S. 1998. Ancient Boats in North-West Europe. The Archaeology of Water Transport to AD 1500. London and New York: Longman.

Milne, G. 2004. The fourteenth-century merchant ship from Sandwich: a study in medieval maritime archaeology. Archceologia Cantiana 124, 227-264.

Myrhøj, H. M. 2000. The late medieval wreck from Vedby Hage, Denmark, in J. Litwin (ed.), Down the River to the Sea (Eight International Symposium on Boat and Ship Archaeology, Gdansk 1997), 229-234. Gdansk: Centralne Muzeum Morskie.

Nævestad, D. 1998. Lokaliserte middelaldervrak i ØstNorge. Norsk Sjøfartsmuseum Årbok, 159-208.

Nayling, N. and Jones, T. 2014. The Newport medieval ship, Wales, United Kingdom. International Journal of Nautical Archaeology 43(2), 239-278.

Nayling, N. and Susperrigi, J. 2014. Iberian dendrochronology and the Newport medieval ship. International Journal of Nautical Archaeology 43(2), 279-291.

Nielsen, X. 2014. Dock Island's Wreck 3: Hull Description and Comparative analysis of a Fifteenth Century Clinker Built vessel, with a Review of its Documentation Methodology. Unpublished Master's thesis. Esbjerg: Syddansk Universitet.

Olesen, J. E. 2005. Riga und Dänemark im Mittelalter, in I. Misāns and H. Wernicke (eds), Riga und der Ostseeraum. Von der Gründung 1201 bis in die frühe Neuzeit (Tagungen zur Ostmitteleuropa-Forschung 22), 180-192. Marburg: Herder Institut.

Overmeer, A. 2006. Searching for the missing link? A research on clinker built ships in the fifteenth and sixteenth centuries. SOJA-bundel 2006, 63-72.

Overmeer, A. 2008. Schepen van verre kusten? Overnaadse schepen in Nederland in de 15de en 16de eeuw, in R. Oosting and J. van den Akker (eds), Boomstamkano's, overnaadse schepen en tuigage (Inleidingen gehouden tijdens het tiende Glavimans Symposion, Lelystad 2006), 41-55. Amersfoort: Glavimans Stichting.

Overmeer, A. 2009. Scheepswrak aan het Wrakkenpad. Waardestellend onderzoek van scheepswrak B 36, gemeente Nordoostpolder (Grondsporen: Opgravingsen onderzoeksrapporten van het Groninger Instituut voor Archeologie 5). Groningen: Rijksuniversiteit Groningen.

Overmeer, A. forthcoming. Clinker-built ships in the Netherlands. PhD thesis, University of Groningen.

Pāvulāne, V. 1975. Rìgas tirdzniecība ar meža materiāliem XVII-XVIII gs. Riga: Latvijas PSR Zinatnu Akademija Vestures Instituts.

Reinders, H. R. and Aalders, Y. 2007. Frisian traders and the clinker technique, in T. Arisholm, K. Paasche and T. L. Wahl (eds), Klink og seil - Festskrift til Arne Emil Christensen, 109-122. Oslo: Norsk Sjøfartsmuseum.

Reinders, H. R. and Oosting, R. 1989. Mittelalterliche Schiffsfunde in den Ijsselmeerpoldern, in W. H. Zimmerman and L. Spath (eds), Ländliche und städtische Küstensiedlungen im 1. und 2. Jahrtausend (Wilhelmshavener Tage 2), 107-122. Wilhelmshaven: Nordwestdeutsche Universitätsgesellschaft.

Sauer, A. 1996. Das Seebuch - Das älteste erhaltene Seehandbuch und die spätmittelalterliche Navigation in Nordwesteuropa (Schriften des Deutschen Schiffahrtsmuseums 44). Hamburg: Kabel.

Schwarzwälder, H. 1994. Bremen als Hansestadt im Mittelalter. Hansische Geschichtsblätter 112, 1-38.

Steen, K. 2012. Rapport: Dronning Eufemiasgate Sørenga 8 (Arkeologisk Rapport 8, 2012). Oslo: Norsk Maritimt Museum.

Teisen, M. 1994. A medieval clinker-built wreck at Hundevika, Norway, in C. Westerdahl (ed.), Crossroads in Ancient shipbuilding (Proceedings of the Sixth International Symposium on Boat and Ship Archaeology, Roskilde, 1991), 73-76. Oxford: Oxbow Books.

Thowsen, A. 1965. Foldrøyskipet: Et middelaldersk skipsfunn fra Vest-Norge. Sjøfartshistorisk Årbog, 38-57.

Tinniswood, J. T. 1949. English galleys 1272-1377. Mariner's Mirror 35(4), 276-315.

Tossavainen, J. 1994. Dutch Forest Products' Trade in the Baltic from the Late Middle Ages to the Peace of Munster in 1648. Unpublished Master's thesis, Jyväskylä.

Vlierman, K. 1996. Kleine bootjes en middeleeuws scheepshout met constructiedetails (Scheepsarcheologie 2. Flevobericht 404). Lelystad: Rijksdienst voor de Ijsselmeerpolders.

van de Moortel, A. 2011. Medieval boats and ships of Germany, the Low Countries, and northeast France 
- archaeological evidence for shipbuilding traditions, shipbuilding resources, trade, and communication. Siedlungs- und Küstenforschung im südlichen Nordseegebiet 34, 67-104.

Ważny, T. 1990. Aufbau und Anwendung der Dendrochronologie für Eichenholz in Polen. Unpublished PhD thesis, Hamburg: Universität Hamburg.

Ważny, T. 2002. Baltic timber in Western Europe - an exciting dendrochronological question. Dendrochronologia 20(3), 313-320.

Ważny, T. and Eckstein, D. 1987. Der Holzhandel von Danzig/Gdansk - Geschichte, Umfang und Reichweite. Holz als Roh- und Werkstoff 45, 509-513.

Weidinger, U. 2002. Die Entstehung der Schlachte als mittelalterliche Hafenanlage Bremens, in K. Elmshäuser (ed.), Häfen - Schiffe - Wasserwege. Zur Schiffahrt des Mittelalters (Schriften des Deutschen Schiffahrtsmuseums 58), 116-132. Hamburg: Convent.

Zunde, M. 1998/99. Timber export from Old Riga and its impact on dendrochronological dating in Europe. Dendrochronologia 16/17, 119-130.
Zwick, D. 2010. Neues vom 'Beluga Schiff' - ein Bremer Klinkerwrack aus dem 15. Jahrhundert. Nachrichtenblatt Arbeitskreis Unterwasserarchäologie $16,62-71$.

Zwick, D. 2012. Variationen in der mittelalterlichen Schiffbautechnik anhand von Wrackfunden in Bremen. Mitteilungen der Deutschen Gesellschaft für Archäologie des Mittelalters und der Neuzeit 24, 283-298.

Zwick, D. 2014. Conceptual evolution in ancient shipbuilding: an attempt to reinvigorate a shunned theoretical framework, in J. Adams and J. Rönnby (eds), Interpreting Shipwrecks: Maritime Archaeology Approaches

(Southampton Monographs in Archaeology New Series 4), 46-71. Southampton: Highfield Press.

Zwick, D. 2017. A 15th-century shipwreck with Scandinavian features from Bremen (Germany), in J. Gawronski, A. van Holk and J. Schokkenbroek (eds), Ships and Maritime Landscapes (Proceedings of the Thirteenth International Symposium on Boat and Ship Archaeology 8-12 October 2012, Amsterdam), 315-322. Groningen: Barkhuis. 